\title{
聴覚の不快レベルに関する臨床的研究
}

\author{
慶応義熟大学医学部耳兽咽頭科教室（主任：鈴木安恒教授）
}

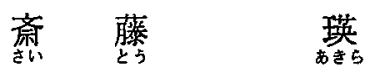

要旨 著者は, 以前から正常者及び難㯖者について不快レベルの測定を行って来ているが, 通常のオ ージメータでは不足することが多い，その為，リォン整オーシォメータ A-1002D にブースタ AE25 を接綂して出力を增強して検查を行っている。なお，测定は純音で行っているが， $125 \mathrm{~Hz}, 8000 \mathrm{~Hz}$ ，は ブースタを使用してるスケール・アウトすることが多いので, $250 \mathrm{~Hz}, 500 \mathrm{~Hz}, 1000 \mathrm{~Hz}, 2000 \mathrm{~Hz}, 4000 \mathrm{~Hz}$ を中心にその成績を分析してみた。

従米，諸家が指摘しているょろに不快レベルの個人差によるバラッキは，かなり大きいるのである が，两耳間の差に着目すれば，充分に臨床的に利用し得るすのである。

得られた結論は以下の如くである。

(1) 正常者の不快レベルは個人差によるバラッキはかなり大きいが, その左右敢間の差は $15 \mathrm{~dB}$ 以内 である。

（2）感音性難聴では, 例えば, メニエル氏病では比較的低值で, 老人性難聴では高値で不快レベルが

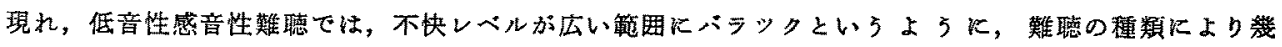
分，不快レベルの現れ方汇差がみられる。

しかし，一般的に云つて，気導閵値の差が $15 \mathrm{~dB}$ 以下であれば不快レベルの左右差が $15 \mathrm{~dB}$ を上わ ることはない。

それ以上の気導閂値の差があれば，

気導闒値の左右差：不快レベルの左右差

$65,65 \mathrm{~dB} \quad: \quad 20 \mathrm{~dB}$ 以下

$70,75 \mathrm{~dB} \quad: \quad 25 \mathrm{~dB}$ 以下

$80,85,90 \mathrm{~dB}: 30 \mathrm{~dB}$ 以下

$95,100 \mathrm{~dB}: 35 \mathrm{~dB}$ 以下

の関倸があると推定される。

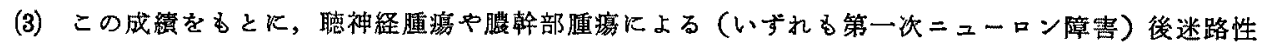
難㯖例を検討すると 1 周波数を 1 例として90\%の周波数が，この勘深を上をわる値を示していた。

な扣，この場合，聴力損失が軽度でる不快レペルの上界が見られるので，不快レベルの測定は聴神経

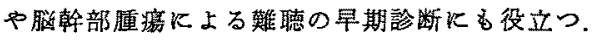

(4) 不快レベルの測定値と，バランステストの関係を平衡戝の上で見てみると，殆んどが一致した值 對していた。

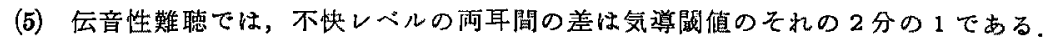

（6）語音明隌度と不快レでルの間には，ある程度関係があるが，バラッキが大きいので語音 明瞭度 は，不快レべルのみで規定されるとは云光ない。

（7）聴力陵害を伴わない hyperacusis の症例の猃断飞不快レベルの測定が役立つことがある.

I はじめに

音を最小可聴間值より次第に強くしてゅくと，閎える 音の大きさ(loudness)は，それに伴って大きくなってゆ くが，その強さがある值紊越えると，通常の音感党とは 異なる感喾が生してくる。例えば, feeling, tickle, touch, pricking，pain 等と研究者によつて名づけられているよ
らな感覚である9゙，こらした感覚の現れる強さに至る途 中で，音が大きすぎもせず，小さすぎもせす，一番快く 聞えてくる強さがある，通常，快適レベル (most comfortable loudness level, comfortable loudness etc.) と呼 ばれているものである。

快適レベルよりも更に音を強くすると音は不快感を伴 
らようになつてくる.これが不快レベル (uncomfortable loudness level, uncomfortable loudness, discomfort level etc.) と呼ばれているものである.

以前より，不快レベルの測定を臨床飞応用しようとい ら試みが行なわれているが，その目的のひとつは，補聴 器の適応や，その出力の上限の決定に利用しよらといら 考えである，例えば Silverman (1947) は，この目的で， discomfort, tickle, painの感觉の闇值を系統的に測定し, 検查を繰返すと閶值がある程度まで上昇してゅく傾向の あることを羿めている11．

もらひとつの試みは，不快レベルをレクルートメント 現象の検出に利用しょうという考えで，例えば，Bangs and Mullins (1953)は, 種々のレクルートメント現象検 查法を比較検討して，快適レべルおよび不快レべルの測 定を利用する the range of loudness method が，最 む 信頼できる方法であると認めている22.

それ以来，この方法が注目され，いくつかの報告が見 られる. Farrior (1958) は, 聴力検査の簡易化の試みと して，A，B，Cの3つの語音を利用して両耳レクルート メント検査を行ない，X, Y, Z,の3つの語音を用いて単 耳レクルートメント検査を半定量的に行なう方法を発表 し，これに不快レベルを利用している3).

わが国では，新井（1955）が，主として快適レベルを 測定して、レクルートメント現象の検出に有効であった と報告している゙）、しかし，立木等 (1957) は，快適レ ベルおよび不快レベルの臨床的応用の可能性について系 統的な検討を加えたところ，被検者間に大きな個人差が 見られ，また疾患耳における観察で注測定成績はさらに 複雑な変動を示し, 快, 不快の感覚は必ずしも loudness のみによつて規定されると断定し難いと述へ，臨床的応 用に関して懐疑的な考えを明かにしている20).

こらした疑問とともに，通常のオージオメータでは不 快レベルの測定に際して，ことに難聴耳では，出力が不 足する場合の多いこともあつて，この方法が，その後広 く日常的に用いられるには至っていない。

ところが，その後 Hood and Poole (1966) は，不快 レベルの測定を後迷路性難聴耳に施行し，その診断に非 常に有効であるという報告を行なつている4．

私どもも，聴覚の機能をより正確につかむためには， auditory area を全体として正しくとらえる必要があると いら考えから不快レベルの測定を臨床的に行なってき て, その結果を1966年のオージオロジー学会等で発表し てきている，そして，この方法が臨床的に有効であり再
検討に值するという印象をうけている．ここで，不快レ ペルの臨床的応用に際して問題になる点のいくつかを明 かにすることを試みた所以である.

\section{II 測定装置}

不快レベルの測定には，リオン製オージオメータ A -1002D にプースタ AE25を接続し，それに附属するレ シーバを用いている.このブースタを使用すると，測定 䉏囲を $125 \mathrm{~Hz}$ で $90 \mathrm{~dB}, 250 \mathrm{~Hz}$ で $105 \mathrm{~dB}, 500 \mathrm{~Hz}$ で $120 \mathrm{~dB}$, $1000 \mathrm{~Hz}$ で $120 \mathrm{~dB}, 2000 \mathrm{~Hz}$ で $120 \mathrm{~dB}, 4000 \mathrm{~Hz}$ で $115 \mathrm{~dB}$, $8000 \mathrm{~Hz}$ で $100 \mathrm{~dB}$ まで拡大することができる.

通常のオージオメータのみで不快レベルの測定を行な うと，出力が不足する場合が非常に多い，後に示すよう に, 正常者では, 通常のオージオメータで測定を行なつ たとしたら，20３0\%程度はスケールアウトすることに なる. 特に $125 \mathrm{~Hz}$ では，60dB 以下に不快レベルが現れ たのは7.5\%にすぎなかつた。

この傾向は難聴のある場合には, さらに強くなり, 内 耳性難聴では，もちろんとりあつから症例の聴力損失の 程度によつて異るであろうが，私どもの場合では，各周 波数で少くとも40 60\%がスケールアウトすることにな るし，伝音性難聴では，不快レベルの大きさの求められ るのは，約10\%に過ぎないことになる.

従つて, 通常のオージオメータを使用して不快レベル の測定を臨床に応用しようとしても，全く不快レベルが 測定できなかつたり，ごく限られた周波数でしか測定で きなかつたりあるいは，片耳だけは不快レベルが求め られても，それが出力の限界に近いために両耳間の差を 検討できなかつたりする場合が大多数であろらと思われ る.もちろん，このような場合でも，症例によつては極 めて有力な診断根拠となる情報の得られることもあるが 一般に通常のオージオメータでは不快レベルを問題にす る時は，いささか出力が不足するといえるようである.

私どもは，以上のような理由からブースタを使用して 測定を行なつているのであるが，それでも出力が不足す る場合がある。ことに， $125 \mathrm{~Hz}, 8000 \mathrm{~Hz}$ では，そうであ る. 後の検討で, この 2 つの周波数をはぶいているのは このためである.

他の周波数についても，後迷路性難聴などでは，さら に亮出力であれば，不快レベルの動態がもう少し詳細に 観察できるのではないかと，もどかしい感じの寸る場合 ああるが，臨床的には，これだけの出力があればまず充 分であると思われた。

なお，例えば Ticle などの感覚が生ずるのは, Silver- 
man によれば 140dB 以上"1)，松崎（1956）によれば130

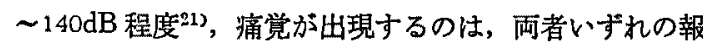

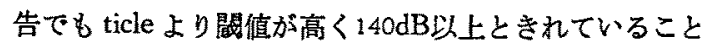
より, 私どもの使用している装羁では，こ5した感覚を 生ずることはほとんどないと思われる、事実，私どるは まだ，痛堂を訴える例に遭遇したことはない，ただ，振 動感とむぼしき感覚を訴える例は， $125 \mathrm{~Hz}$ や250 Hzの低 い音で検查する場合に，時々あつた．しかしここの強さ の音が必すしも不快であるといらわけではないようであ つた.

\section{III 測定方法}

不快レベルの测定には純音を用いている，被検者に は，あらかじめ,音を次第に大きくしてゆきますが，む し少しでる不愉快な感じがしたらボタンを押して下さ い」と指示している. 検查は, 通常は40〜60dBより始

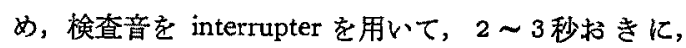
䄪 1 秒間づつ提示しながら, 合図のあるまで, 丁度気導 間做の測定法と同じよらに5dB ステップで強くしていつ て閏值を求める.

測定の覑序は，まず $1000 \mathrm{~Hz} り$ 始め，上述の手順を 数回（通常は 2 回）反復して，求めた閔值が一致した場 合は，続いて反詨耳につマて，同様に $1000 \mathrm{~Hz}$ の不快レ ベルを求める，桧查中に，右耳と左耳を検する際で，被 険者の不快感の criteria が変動方るのをなるべ防ぐベ く，ある周波数の不快レふルは必ず左右耳を続けて測定 することにしているのである.

$1000 \mathrm{~Hz}$ の次は，やはり通常の気導䦎檤の測定法にな らつて, $2000 \mathrm{~Hz}, 4000 \mathrm{~Hz}, 8000 \mathrm{~Hz}$ の順に, 左右耳の測 定を交互に行ない，ここで再ぴ $1000 \mathrm{~Hz}$ に戾り，この值 と，第一回目の測定值の至が5dB 以内であれぱ，続いて $500 \mathrm{~Hz}, 250 \mathrm{~Hz}, 125 \mathrm{~Hz}$ の順で, やはり, 左右耳交互に 測定していく.

しかし，前にむ触れたよらに難聴耳では，8000 $\mathrm{Hz}$ と $125 \mathrm{~Hz}$ の不快レベルは，こうしたブースタを用いてもス ケールアウトすることが多いので，特別な場合を除いて は，その測定を省略してもよいように思う。

また，記録は，オージオグラム上に，右耳の不快レベ ルをへ，左耳の不快レベルをりで能入することにしてい る.

なおこの方法は，Bangs and Mullins の行なつた方

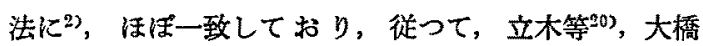

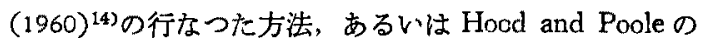
方法゙にほぼ等しいるのとわれる。

\section{IV 正常 者}

正常者 (既往歷, 自喾症状, 視猃所見拉よび通常の気 導閶值検查で異異を䏸めない，つまり各周波数で気導聴 力椇失が $15 \mathrm{~dB}$ 以下であつたものを正常者とした）20名 40耳につルて測定を行なつた，な被険者の年令は15才 から20才までであつた。

\section{[成繢]}

測定結果は，第 1 図および第 2 図に示してある。第 2 図は第 1 図と同しであるが，周波数別に気導闘值と不快 レベルの散らばり具合を判りやすいよらに示したもので ある。

不快レベルがスケールアウトしたすのは，125Hzに 2 耳 ( 2 名)，8000Hzに 6 耳 ( 3 名) あつたのみで，他の 周波数では，全員に不快レベルの值を求めることができ

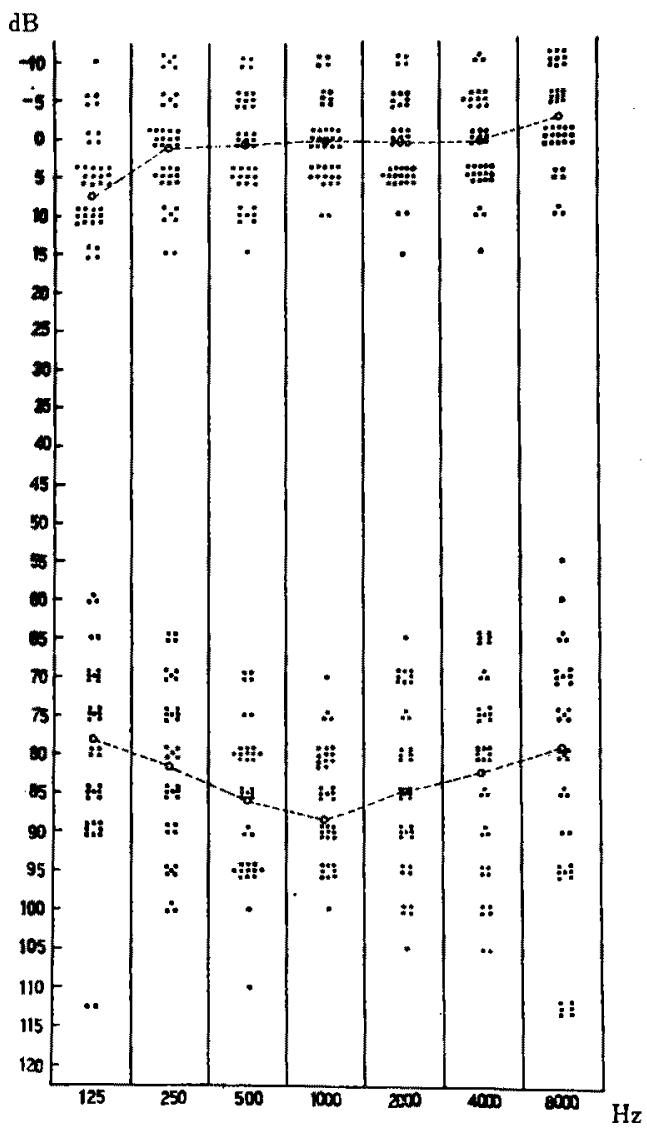

第 1 图正常者の気導閶值と不快レベル 図の上部は気筫䦪值, 下部は不快レベル，点楾 は夫々の平均倠を結んでいる。 
(1) $250 \mathrm{~Hz}$

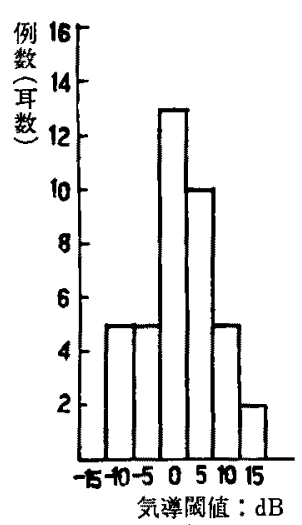

(2) $500 \mathrm{~Hz}$
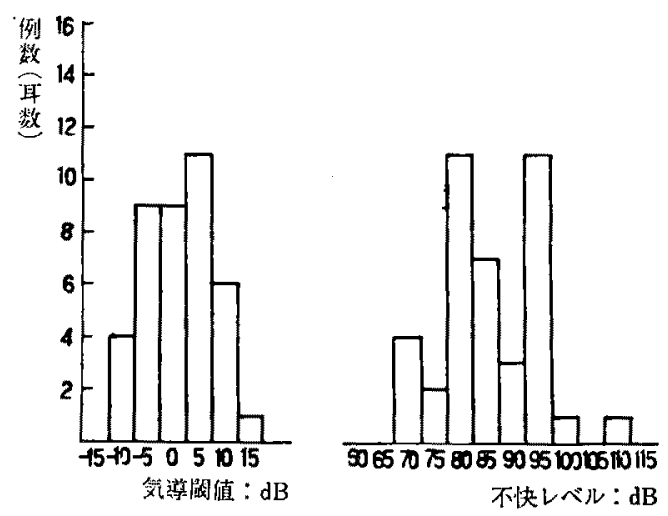

(3) $1000 \mathrm{~Hz}$

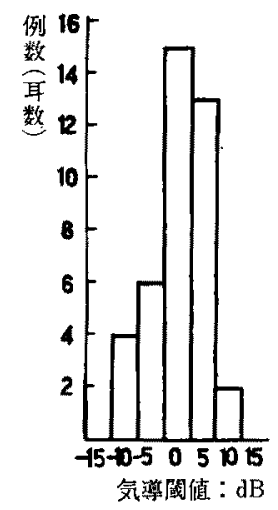

(4) $2000 \mathrm{~Hz}$

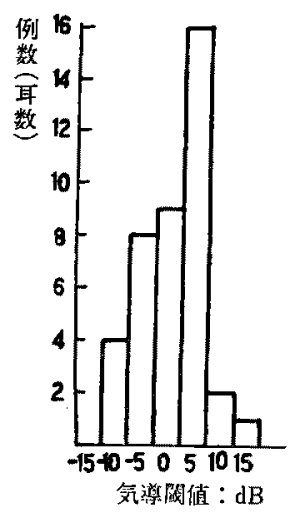

(5) $4000 \mathrm{~Hz}$
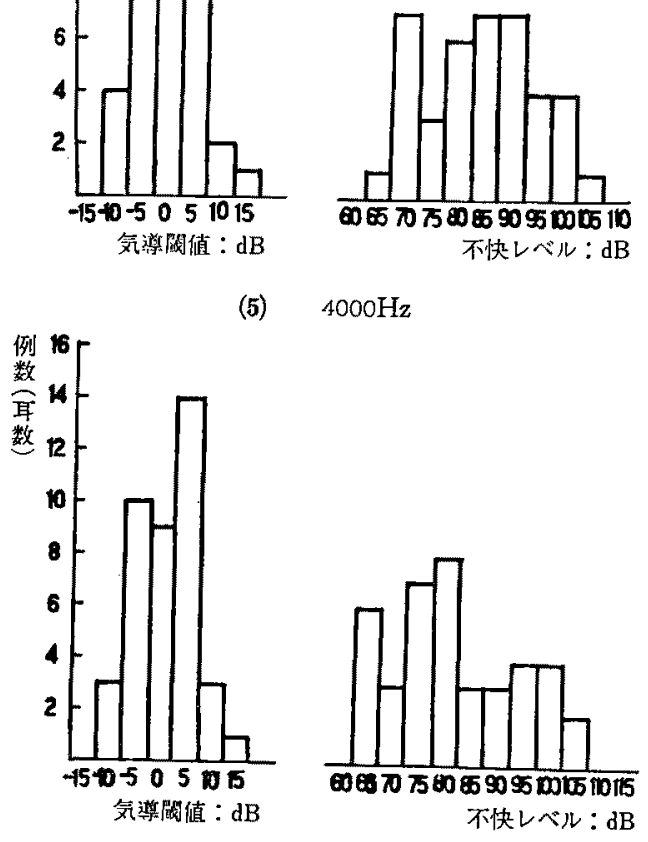

た.しかし，前述したよ5に難聴者においては，125 Hz $8000 \mathrm{~Hz}$ では，测定不能の例が 非常に多く分析の対象に し難、ために，ここでも250〜 4000Hzを中心に検討を行 なつた.
第 2 図 正常者の気導關值と不快レベル

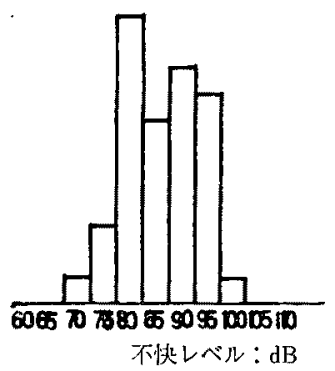

正常者の不快レベルの平均は第 1 表に一括して示した が，およそ80 90dB程度であつた，散らばり具合につ いては，標準偏差から考えて，平均值の上下 15 25dB 程度の範囲に分布するるの考えられ，かなりバラッキ 
第 1 表 正常者の気尊閥值と不快レベル

\begin{tabular}{|c|c|c|c|c|c|c|}
\hline & \multicolumn{2}{|c|}{ 気遒間值 } & \multicolumn{2}{|c|}{ 不快レペル } & \multicolumn{2}{|c|}{ 不快レベル } \\
\hline & $\begin{array}{r}\text { 平均值 } \\
: \mathrm{dB}\end{array}$ & 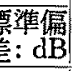 & $\begin{array}{r}\text { 平均值 } \\
\quad \mathrm{dB} \\
\end{array}$ & $\begin{array}{l}\text { 標準䓲 } \\
\text { 差: } \mathrm{dB}\end{array}$ & $\begin{array}{r}\bar{F} \text { 均值 } \\
\quad \mathrm{dB} \\
\end{array}$ & $\begin{array}{l}\text { 禋準偏 } \\
\text { 差: } \mathrm{dB} \\
\end{array}$ \\
\hline $125 \mathrm{~Hz}$ & 5.5 & & 77.9 & & & \\
\hline $250 \mathrm{~Hz}$ & 1.4 & 6.7 & 81.6 & 10.6 & 80.4 & 12.2 \\
\hline $500 \mathrm{~Hz}$ & 1.1 & 6.6 & 85.8 & 9.3 & 84.9 & 10.3 \\
\hline $1000 \mathrm{~Hz}$ & 0.4 & 4.8 & 87.9 & 2.4 & 86.0 & 8.0 \\
\hline $2000 \mathrm{~Hz}$ & 0.9 & 5.5 & 84.3 & 10.5 & 83.9 & 12.8 \\
\hline $4000 \mathrm{~Hz}$ & 0.9 & 6.0 & 82.0 & 12.2 & 81.0 & 14.5 \\
\hline $8000 \mathrm{~Hz}$ & -2.5 & & 78.7 & & & \\
\hline
\end{tabular}

が大きいことがわかる。

不快レベルの平均值をオージオグラム上で結ぶ，1000 Hzを底とする谷型になつた (第 1 図)，但し，その差は， $1000 \mathrm{~Hz}$ と，250Hz は低值をとるといえるが，その他の 周波数間には有意の差があるといえる程ではなかつた ( $\mathrm{t}$-検定. 危険率 $1 \%)$ 。このカーブの形は, Silverman の報告のカーブと相似しているが, Silverman は，これ について，不快レベルの示すカーブは，強い音の場合の equal-loudness contour と一致するものであると考えて マる(11).

次に，周波数が異ると不快レベルの散布に差があるか ゼらかを調べてみると，1000 Hzでは，ややバラッキが 少、といえるが，その他の周波数の間では，とりたてて 差があるとはいえないようであつた（下検定．危険率 5 $\%$ ).

不快レベルは，このよらに個人間でかなりバラツキが 大きいものであるが，次に両耳間の差を見たのが第 3 图 である。便宜上，250 40000 Hzの各周波数の 左右差を 一括して示している. 左右差の平均は $0.25 \mathrm{~dB}$ で, 標準
不快レベルの左右差： $\mathrm{dB}$

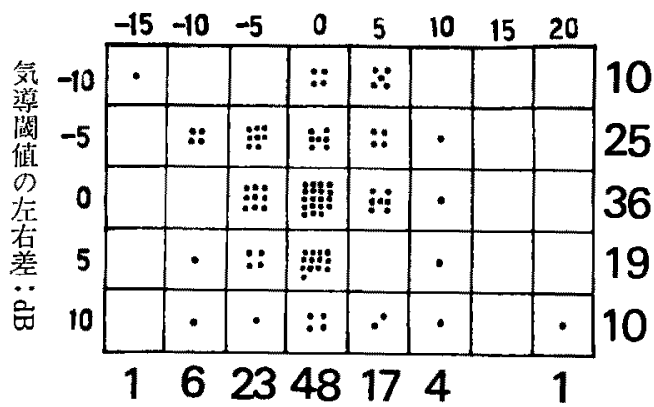

第 3 図 正常者に和ける不快レベルの左右差 (250 4000Hz を一つの図に表してある)

偏差は5.14dB であつた. 全例で, 左右差は10dB 以下で あつたが，標準偏差からいつて，一般に不快レベルの左 右差は $15 \mathrm{~dB}$ 以下であるといえよう，立木等の，両耳閒 の差は，通常5〜10dB の間であるとの報告に一致した成 續であつた ${ }^{20)}$.

\section{[考按]}

この成嘖を従来の報告と比べてみると，第 2 表に示し たように大橋 ${ }^{14)}$ ，立木等 ${ }^{200}$ の報告とは，かなり一致して いるといってよいと思われる. Hood and Poole ${ }^{4)}$ の報告 とは，10dB を越す差がいずれの周波数でも見られるが， これは，招そらくオージオメータの違、（すなわち $\mathrm{dB}$ の違い）によると思われる. 英国の $0 \mathrm{~dB} の$ 基準は，わが 国のそれよりも10dB 强は低いと考えられるからであ $ろ^{17}$.

なお，Silverman の実験では，不快感が110dB 程度で 出現することになつているが，彼の場合はインターバル をおかずに連続的に音圧を上げていつて测定しているの で11)，この点に差を生ずる原因があるのではないかと思

第 2 表 餜 家 $の$ 報 告

\begin{tabular}{|c|c|c|c|c|c|c|c|c|}
\hline & \multirow{2}{*}{\multicolumn{2}{|c|}{$\begin{array}{c}\text { 立木等 }(1957)^{20)} \\
\text { S. L. }\end{array}$}} & \multicolumn{4}{|c|}{ 大 欈 $(1960)^{4)}$} & \multirow{2}{*}{\multicolumn{2}{|c|}{$\begin{array}{c}\text { Hood et al. }(1966)^{4)} \\
\text { S. P. L. }\end{array}$}} \\
\hline & & & \multicolumn{2}{|c|}{ S. P. L. } & \multicolumn{2}{|c|}{ S. L. } & & \\
\hline & 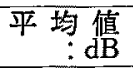 & 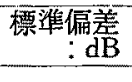 & 平均値 & $\begin{array}{r}\text { 標準偏羙 } \\
: \mathrm{dB} \\
\end{array}$ & $\begin{array}{c}\text { 平均值 } \\
\vdots \mathrm{dB}\end{array}$ & $\begin{array}{r}\text { 標準偏厓 } \\
\vdots \mathrm{dB} \\
\end{array}$ & $\begin{array}{r}\text { 平均值 } \\
\mathrm{dB}\end{array}$ & $\begin{array}{r}\text { 標準偏栲 } \\
: \mathrm{dB} \\
\end{array}$ \\
\hline $250 \mathrm{~Hz}$ & & & 74.25 & 8.55 & 63.37 & 7.05 & & \\
\hline $500 \mathrm{~Hz}$ & 86.5 & 14.8 & 77.37 & 7.75 & 72.37 & 9.55 & 98 & 90 \\
\hline $1000 \mathrm{~Hz}$ & 85.25 & 14.3 & 75.50 & 6.10 & 74.68 & 6.45 & 98.2 & は \\
\hline $2000 \mathrm{~Hz}$ & 80.4 & 15.5 & 77.81 & 5.80 & 77.06 & 8.30 & 98.9 & \\
\hline $4000 \mathrm{~Hz}$ & 78.3 & 13.5 & 78.05 & 7.25 & 75.67 & 8.20 & 95 & $105^{\prime} \mathrm{dB}$ \\
\hline $8000 \mathrm{~Hz}$ & & & 71.56 & 7.30 & 68.87 & 8.80 & & \\
\hline
\end{tabular}


われる。

第 1 表に戻って，不快レベルを，オージオメータのダ イアルの読み, つまり SPL で記載した場合と, 不快レ ベルと気尊闘值の差,つまり SLで記载した場合の標準 偏差を較べてみると，いずれの周波数でも SLの方が， バラッキが大きくなっている. Hood (1968) は, 正常耳 においては，気導闒値の如何に拘らず，不快レベルがほ ぼ一定の SPL で現れることを示し，正常者の気尊闇值 のバランキは内耳性の原因によって起つてくるものであ ると論しているらかが，著者の成績でも，第 2 表に示した 大橋の報告ででも同様のことがいえる14).

だが，例え SPL で記述した場合でも，やはり個人間 のバラツキは大きいのであるから不快レベルの測定を臨 床に応用する場合に，そのいはば䋓対値 (SPL でも SL でむ）を以つてしては，誤りを扔かす可能性大がきいの である.しかし，その両耳間の差は，これと対照的にバ ラッキが少いものであるから，この点に着目すれば充分 に臨床的に応用できるものと予想される。

従来，不快レベルが，あまり臨床的に利用されていな 、理由は, もちろん, 通常のオージオメータでは出力が 不足するためむあるが，こうした観点からの検討が充分 行なわれていなかつたためむあろらかと思われる。

私どもはここうした理由で，常に両耳間の差に注目し て不快レベルの測定を臨床に応用し，またその観点から 分析を行なっているのである.

\section{$\mathrm{V}$ 感音性難聴（後迷路性難聴を除く）}

内耳性難聴と思われる 114 例の不快レベルの測定の結 果を検討したが，その内訳は以下のごとくである．

\begin{tabular}{|c|c|}
\hline$x=$ & 22例 \\
\hline 老人性難聴 & 11 例 \\
\hline 騒音性難聴 & 3例 \\
\hline ストマイ難聴 & 5例 \\
\hline 突発性難聴 & 28例 \\
\hline 低音性感音性難聴 & 7例 \\
\hline 頭部外傷後内耳障害 & 7例 \\
\hline その他 & 31 \\
\hline
\end{tabular}

[成績]

测定結果は，第 4，5，6，7，8 図に示してある. なお，両耳に難聴のあつた場合は，それぞれの值を記入 しているので度数の総計は症例数を上まわつている. この中には, 聴力損失値が非常に大きいものが含まれ ているが，少くとも気導間值が測定できる場合には，不
快レベルがスケール・アウトする症例の非常に少いこと が注目される．特に $500 \mathrm{~Hz}, 1000 \mathrm{~Hz}, 2000 \mathrm{~Hz}$ のよらに $120 \mathrm{~dB}$ まで測定可能な周波数では，検查した 134 耳の内， スケール・アウトしたものは，僅かに 2，3耳のみであ ১た.

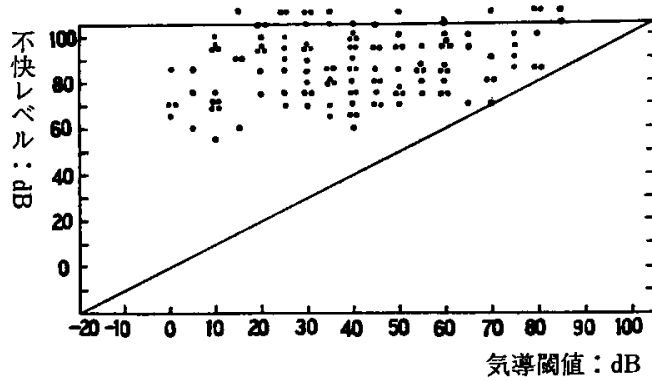

第 4 図 後迷路性難聴を除く各種感音性難聴耳 の不快レベル $(250 \mathrm{~Hz})$

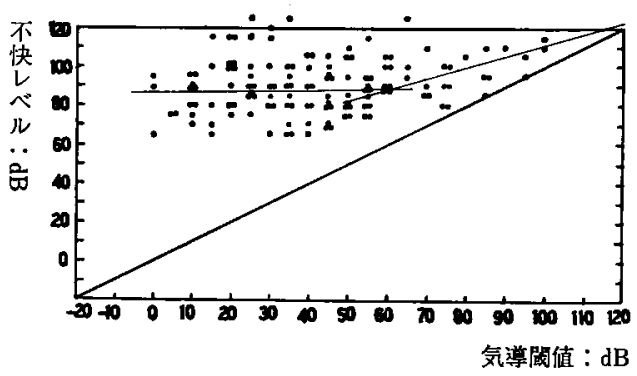

第 5 図 後迷路性難聴を除く各種感音性難聴耳 の不快レベル $(500 \mathrm{~Hz})$

回帰直線 左: $Y_{1}=0.016 X+87.328$ 右: $Y_{2}=0.569 X+54.224$

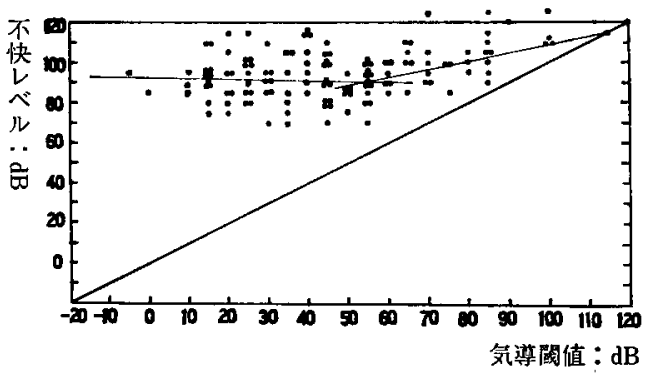

第 6 図 後迷路性難聴を除く各種感音性難聴耳 の不快レベル $(1000 \mathrm{~Hz})$

回帰直線 左: $Y_{1}=-0.045 X+93.318$ 右: $Y_{2}=0.389 X+71.037$ 


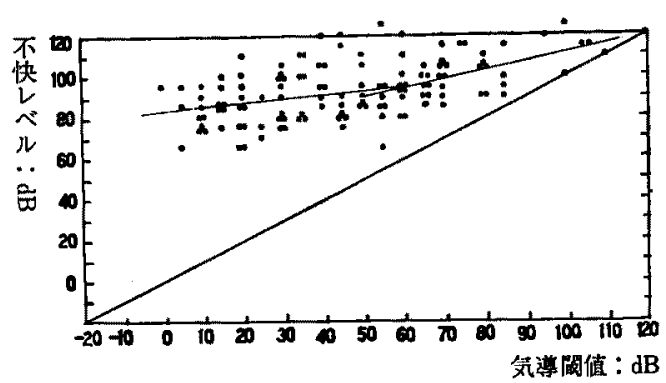

第 7 图 後迷路性難聴を除く各種感音性難聴耳 の不快レベル $(2000 \mathrm{~Hz})$

回㷌故線 左 : $Y_{1}=0.138 X+82.917$ 右 $=Y=0.447 X+66.488$

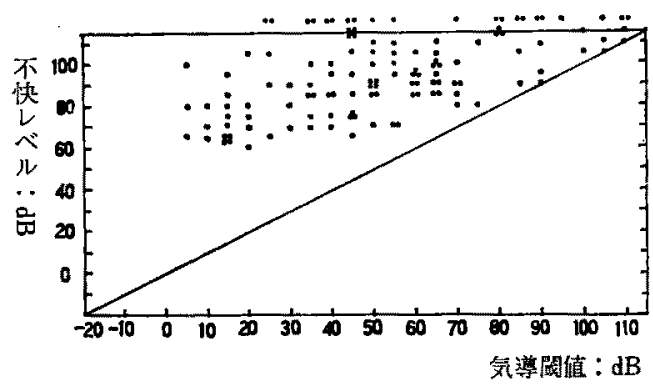

第 8 图 後迷路性難聴を除〉各種感音性難噮耳の不快レベル $(4000 \mathrm{~Hz})$

これらの図は，一見すると，不快レぶルは，聴力損失 の程度により特に影響をらけていないよらな印象を与え るが，当然のことながら，気導聴力損失が非常に大きな 㥁になれば，第13図に示したよらに不快レベル恃気導曲 線の接近のために，これに押し下げられるよらに大きい 值をとるよらになる。

そこで，どの程度の聴力損失があれば不快レベルが上 䄯し始めるかといらことであるが，各気導損失值毎に不 快レベルの平均をとつてみると，50dB 附近を境にして 上昇傾向が現われるようであつた．そこでこれを境に して，その左右で，2本の回㷌直線をひいてみたのが第 5，6，7図に示した回帰線である。いずれの図でも左 側の回帰淔線は勾配が にに近いが，右側の回帰㨁線に関 しては，明かに不快レベルの上畀の傾向が現れている。

こらした㑯向をも5少し正確に検討してみたのが第 9 図である、これは片耳が全く正常で，片耳に内耳性難聴 のあつた症例を選んで, 縦軸に不快レベルの左右差を， 横軸に気尊閔值の左右差をとつて示したむのである。差

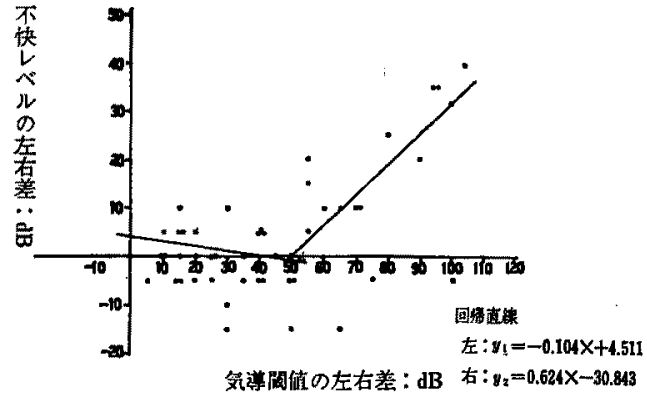

第 9 図(1) $500 \mathrm{~Hz}$

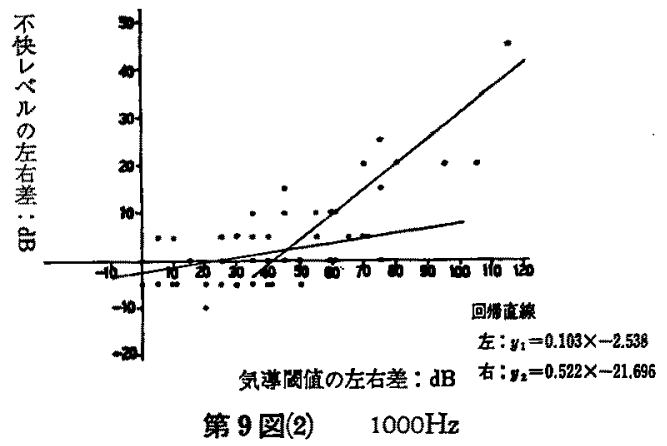

をとつたのは，個人差をできるだけ少くしよ5としたた めである. やはり同様に 40〜50dB を境にして，それ以 下であれば不快レベルは，ほとんど不変であるが，それ 以上の気導間値の上年が起ると不快レベルも次第に上昇 し始めることが判る。

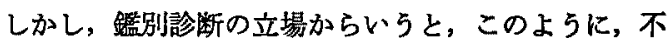
快レベルの、はば絶対值の動きを調べても，必ずしも明 快な鑑別の基準を作り難いのは，その個人間のバラッキ が大きいためで，例えば後述する後迷路性難聴の場合で も，伝音性難聴の場合でも，少くとも不快レベルの測定 できたものに関しては，いかなる場合でも，その值のみ で，内耳性難㯖と鑑别できないことは图を見れば明かで ある。

そこで両耳間の不快レベルの変動を見たものが第了表 である.これには250〜4000Hzをひとまとめにして図示 してあるし，兩耳に内耳性難㯖のある症例も含んでい る.このよらにひとつの図にまとめることは多少，周波 数が違らとバラッキも違らであろらから問題があるが， 臨休上の criteria を求めるためには，繁雑にならないで 良いと思加る。

この暞関表でも， $55 \mathrm{~dB}$ 程度を境にして 2 本の回帰直 線をひくことができるようであつた，気膁聴力損失の両 
耳間の差が55dB 以下では，不快レベルの左右差が $15 \mathrm{~dB}$ を越えるものは極めて少ないが，気導閏值の差が，この 值を越すと不快レベルの左右差も，15dB を越すものが 増し，気道聴力損失が反対耳より大きいにもかかからず 不快レベルがこれより低、値を示するのの数が減少して くるのである.

$55 \mathrm{~dB}$ を境にして左則の回帰直線を計算してみると， $y=0.054 x-0.083$

が得られ，気尊閶値の左右差が增しても不快レヘルの左 右差は，きかめて僅かしか増加しないことがわかる，た だし，0.054の勾配は，t-険定を行ならと，5\%の危険 率では，必ずしも勾配０に等しいということはできない の $\left(t_{0}=2.266\right)$ で，僅加であるが增加しているすのと思 われる.

次に，気導闔值の差が55dB 以上であつたものでは， $\mathrm{y}=0.289 \mathrm{x}-12.589$ となつた。

なお，付記すると，(1)，(2)とも，一次回帰と考えて上 いことはF検定（危険率 $5 \%$ ）で認めることができる.

次に，その回帰直線からの標準偏差を計算してみる と，(1)に関しは6.71dB，(2)に関し は9.19dBとなつた. そこでるら少し詳しく検討すると，

(1) 気導闘值の両耳間の差が $55 \mathrm{~dB}$ 以下であれば，不 快レベルが上昇して，そのため左右差を生ずるとして も，標準偏差6.71dB 上り計算して，その差が $15 \mathrm{~dB}$ を越 えるものは， $0.013 \%$ 程度しかないことになる（悪い方 の耳の不快レベルが下降して生ずる左右差は実際上問題 にならないことが多いと思われるので一端検定を行なつ た.).

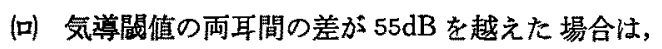
症例数が少いので正確さを欠くららみがあるが，一応試 算してみると，5\%の危険率で，

気導關值左右差：不快レベル左右差

$$
\begin{array}{rll}
60,65 \mathrm{~dB} & : & 20 \mathrm{~dB} \text { 以下 } \\
70,75 \mathrm{~dB} & : & 25 \mathrm{~dB} \text { 以下 } \\
80,85,90 \mathrm{~dB} & : & 30 \mathrm{~dB} \text { 以下 } \\
95,100 \mathrm{~dB} & : & 35 \mathrm{~dB} \text { 以下 }
\end{array}
$$

になる.

W 第 3 表には，気導關值が，良耳の不快レベルより 高値を示した場合は除いてあるが，こらしたものだけを まとめたのが第10図で，例によって250 4000 Hz の結果 を一括したのが第11図である，気尊閩值と不快レベルの 差が20dB を越すものはなかつた。
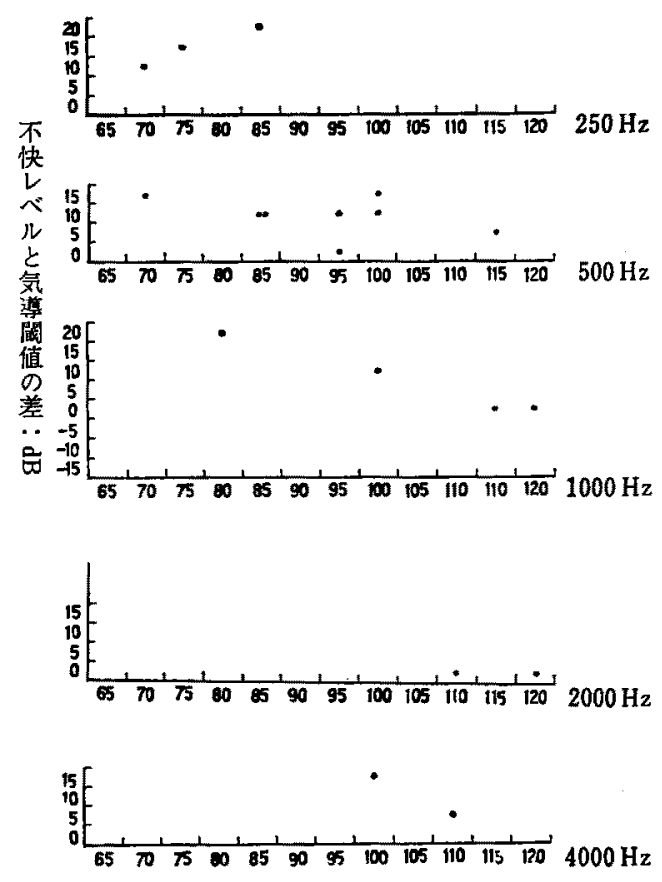

気導闌值： $\mathrm{dB}$

第10図 気導間值が反対側の耳の不快レベルを 越えた耳について（後迷路性難聴を除 〈各種感音性難聴耳）

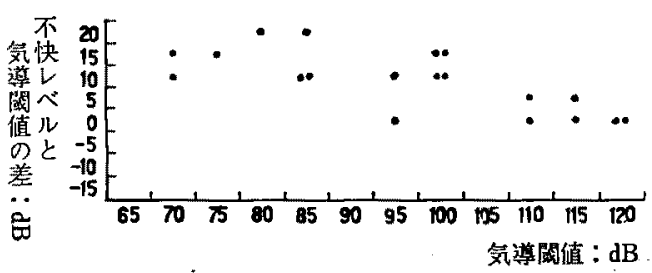

第11図 気導䦪值が反対側の耳の不快レベルを 越えた耳について（後迷路性難聴を除 く感音性難聴. $250 \sim 4000 \mathrm{~Hz}$ を一つの 国に表してある.）

ただ、この場合で不快レベルがスケール・アウトした ものが, $250 \mathrm{~Hz}$ で 2 例, $1000 \mathrm{~Hz}$ で 1 例, $2000 \mathrm{~Hz}$ で 1 例 あり，250Hzの1例は，少くとも気遒間值と不快レベル の差が30dB を越すものと推定される.

しかし，いずれもしろ，こうした場合には，不快レ心゙ ルが測定できるといらだけで，まず内耳性難聴と判定し てもよいように思われる。

[考按]

感音性難㯖耳に和いては，個々の例を見ると，気導闒 
值が上昇しているに拘らず不快レデルが正常耳と較べ て，下降する場合，不変の場合，抢よびある程度上㫒す る場合があるよ5に思われる(第12，13，14図）。

しかし，数多くの症例を見ると不快レベルは気導䦥値 の如何によらず，症例によるバラッキはあるが全体とし てはほとんど影響をらけないように見える。

立木等によれば，このこと注，感音性難聴耳では，不 快レベルは（SLで），正常值より低い值を示すものが多 く，一定の傾向が減少してゆく，と表現され²0)，大橋に

K.S. 24才 女性 メニエル氏病（左） 今右耳 V左耳 不快レベル

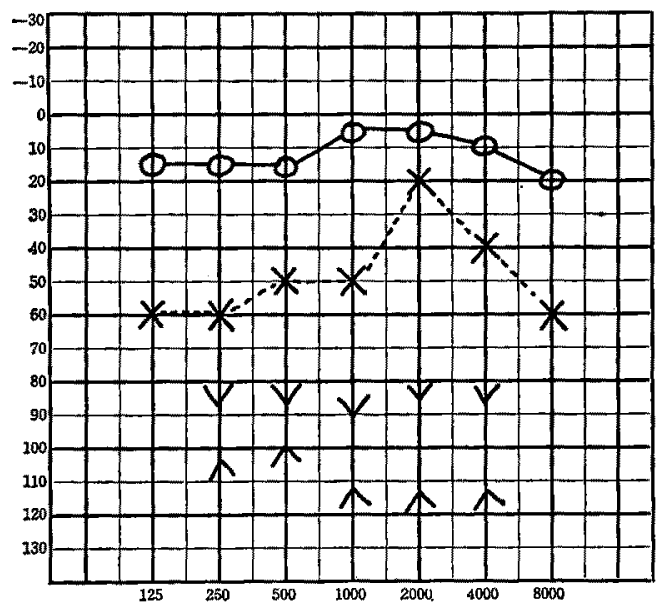

第 12 図

S.S. 41 才 男 $x=$ ニル氏病（右）

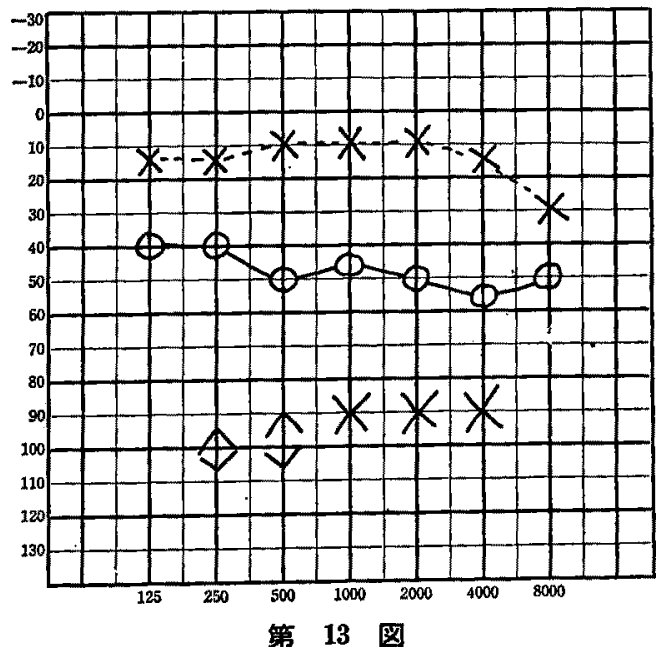

M. U. 49才 女性 笑発性難聴（左） $\wedge$ 右耳 V左耳 不快レベル

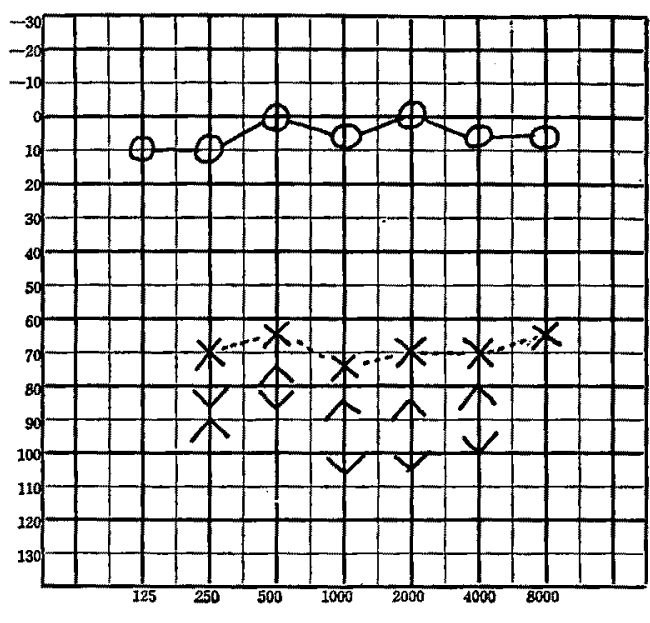

第 14 国

よれば（SPL で），難聴の程度が 進むに従、上昇の傾向 があるが，伝音系難聴とくらべると，その傾向は僅かで あって，そのほとんどが正常耳のレベルの範囲内に集中 的にみられると表現されているい゙．

また, Hocd and Poole む, 正常耳之, 内耳性難聴耳 の場合を比較して，後者の聴力損失の度合の如何によら お゙，両者の差はほとんどみられないと述べている゙).

しかし，さらに詳しく険討すると，例えば大橋が，老

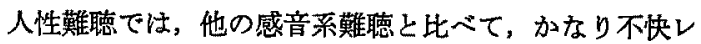
ベルの上昇があるむのを見ると述べているように巡， あ る種の難聴では，他のむのと多少異つた傾向を示すこと もあるようである。

$\rtimes$ ニエル氏病，老人性難聴，低音性感音性難聴を区別 して図示してみたのが第15図であるが，それぞれの難聴 によつて低音が主に障害されるものと，高音が主に障害 されるもののあることを考えて $250 \mathrm{~Hz}$ と $2000 \mathrm{~Hz}$ の測定 值を示してある。

いずれの周波数でも，メニエル氏病の患耳では，不快 レベルは比較的低い值を示し, 老人性難聴では傐い值を 示す傾向がある。

一方，低音性感音性難聴では，不快レベルが低い值ま で，かなり広、範囲に現れてくる。

こらした状態は, ある程度, その難聴の状態を反映し ているよらにも思われる，例えば，老人性難聴では古く からレクルートメント現象のみられないことがあるとい われ，メニエル氏病では hyperacusis の傾向が強く， 
第 3 表 後迷路性難聴を除く各種感音性難聴耳における不快レベルの左右差 $(250 \sim 4000 \mathrm{~Hz})$

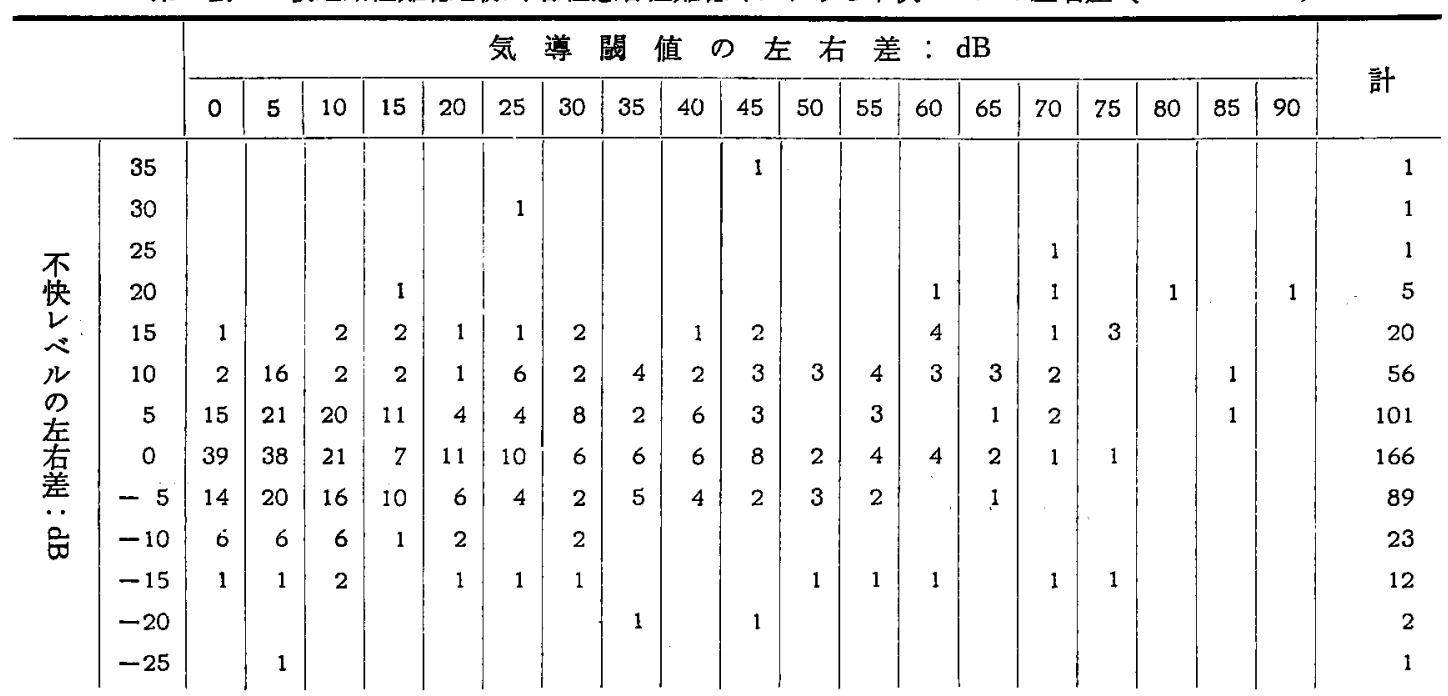

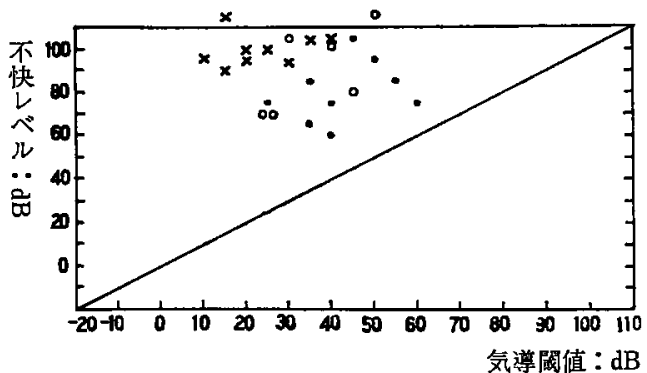

(1) $250 \mathrm{~Hz}$

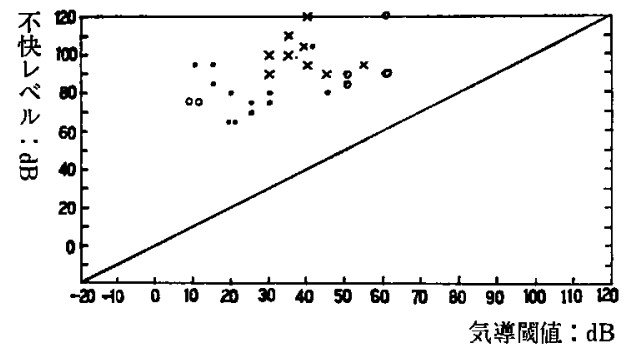

(2) $2000 \mathrm{~Hz}$

第15図 病因別にみた感音性難聴耳の不快レベル

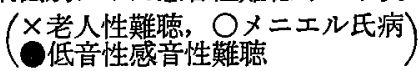

レクルートメント現象が典型的に現れる，という具合に である，また低音性感音性難聴では，同じよらなオージ オグラムでありながら語音明瞭度の非常によいものと，
わるいるのがあるが，これは後述するように，不快レベ ルが聴覚の dynamic rangeのひとつの表現であると考 えれば，やはりその特徴が現われているということがで きるであろう。

また，回帰直線(1)に関する 標準偏差は $6.71 \mathrm{~dB}$ であつ たが，正常者の左右差の標準偏差 $5.14 \mathrm{~dB}$ と比べると明 かに大きくなっている. こうした差の生ずる理由のひと つとしても，難聴の種類が異ると，同じ内耳障害であつ ても不快レベルが，多少とも高值をとつたり低值をとつ たりする傾向のあることをあげることができると思われ る.

\section{VI 後迷路性難聴}

ここで扱つた後迷路性難聴例の内訳は，聴神経腫瘍 11

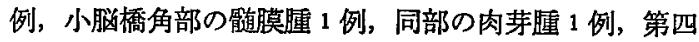
脳室府の神経膠腫 1 例（いずれも手術揖よび病理検査が 確められている)，および種々の聴力検査の成績で 後 迷 路性難聪の所見を呈しているが病理学的な確診の得られ ていない1例の計15例である、いずれも片側性の障害で あり，第一次ニューロンの障害であると思われた，従つ て以下後迷路性難聴と述べるのは第一次ニューロン障害 を指していることを付言しておく．

[成績]

不快レベルの測定值は，周波数別に，第 $16 ， 17 ， 18$ ， 19，20図に示してあり，250 4000Hz をひとつの図にま とめたのが第20図である，不快レベルの左右差を表にし たのが第 4 表である. 


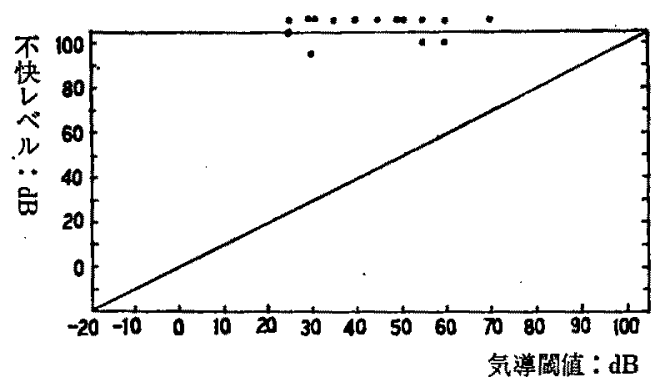

第16图 後迷路性難聴耳の不快レベル $(250 \mathrm{~Hz})$

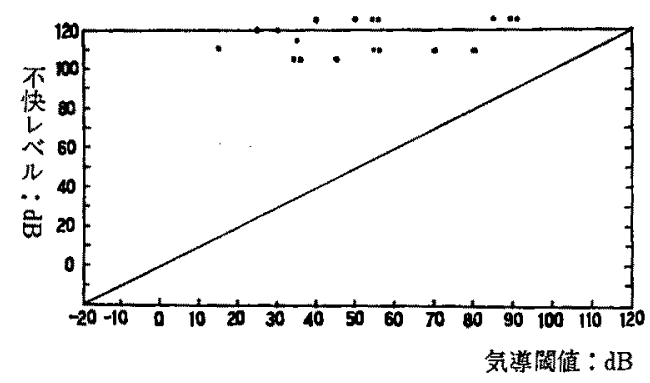

第17图 後迷路性難聴耳の不快レベル $(500 \mathrm{~Hz})$

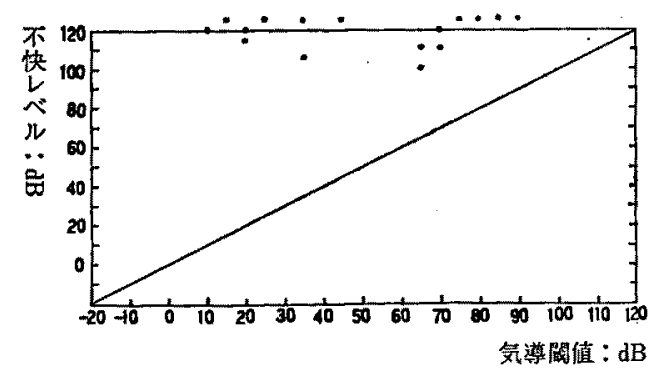

第18图 後迷路性難聴耳の不快レベル $(1000 \mathrm{~Hz})$

第21図をみると，例え気導聴力損失が軽度でも，不失 レベルが明かな上开傾向を示していることがわかる，第 4 表の左右差をみても同憡である。

また，第21四では，気䁶最值の如何によらず，スケー ル・アウトしたものと測定できたものとが，ほぽ相半ば しているので，後迷路性難聴では，例え埾度でも，平均 $120 \mathrm{~dB}$ 程度まで不快レパル梳上昇するものであるといえ よ5. 表 3 の場合注スケール・アウトしたものが多いの で正確なことはいえないが，左右差でいえば，約 $30 \mathrm{~dB}$ の不快レベルの上䒜が起るといえそらである。このこと は, 不快レベルの測定が後迷路性難聴の早期診断に役立

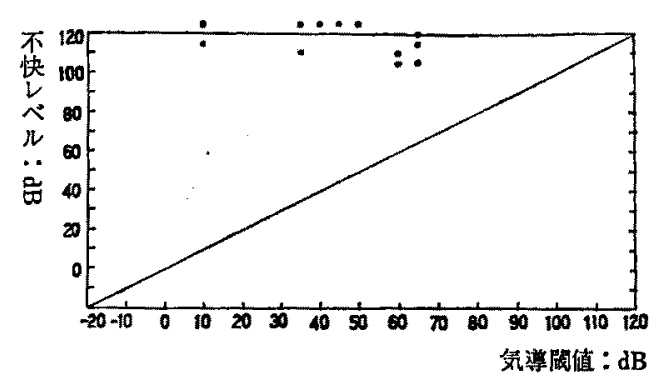

第19图 後迷路性難聴耳の不快レベル $(2000 \mathrm{~Hz})$

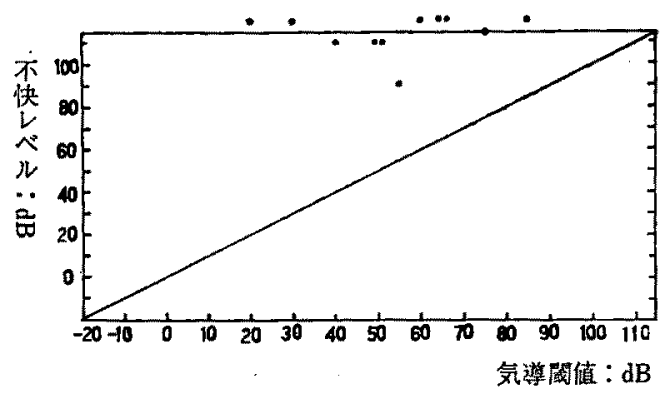

第20図 後迷路性難聴耳の不快レベル $(4000 \mathrm{~Hz})$

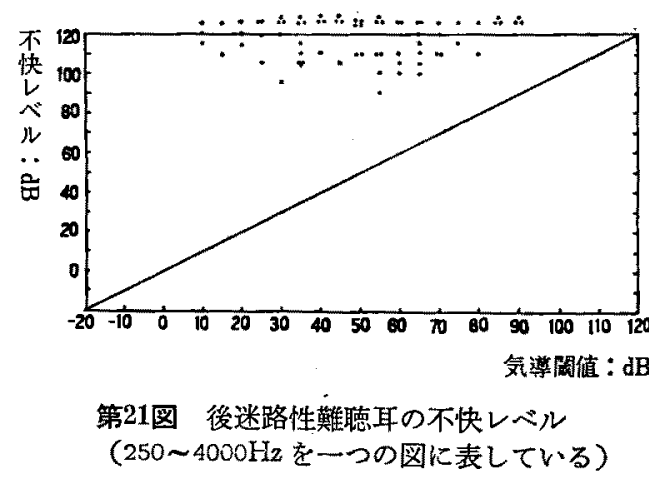

つことを示す所見と思われる。

不快レベルの上年が鳁力損失の增大に相偆5傾向があ るかどらかは，あまり明かでないが，第 4 表を付細にみ ると，気導闌值の差が大きければ不快レぶルの左右差も 大きくなるよ5に見える。しかし症例の少いことるあり 正確なことはいい難いと思われる.

\section{[栲按]}

Hood and Poole は，後迷路性晖聴では，ほとんどの 例で不快レベルが120dB をスケールアウトしたとして， 聴力損失の如何によらず不快レベルの測定が可能であつ 
第 4 表 後迷路性難聴耳にお゙ける不快レベルの左右差 $(250 \sim 4000 \mathrm{~Hz})$

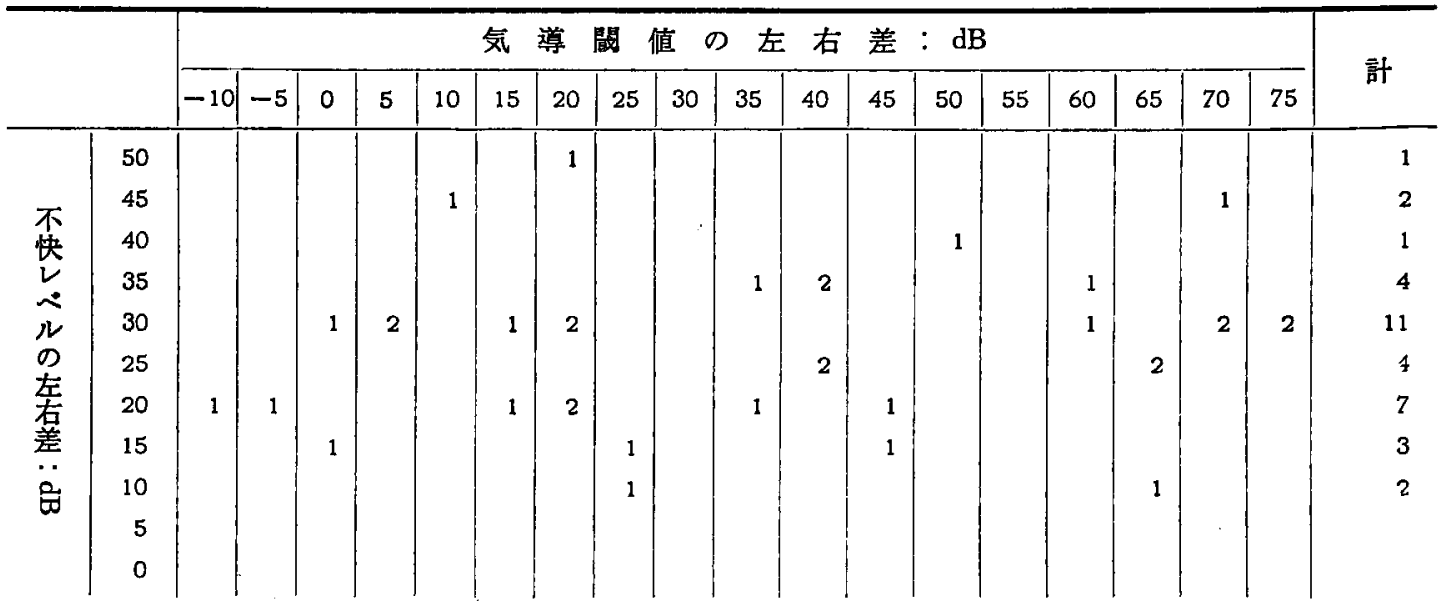

た内耳性難㯖とは，この点で鑑別し得ると述べている゙〉 が, 著者の成績では，前に触れたオージオメータの $\mathrm{dB}$ の違いにもよるだろらが, 後迷路性難聴の半数で不快レ ベルの測定が可能であつた. 従って Hood and Pooleの 基準では，鑑別が難しかつたといかなければならない。

そこで, 後迷路性難聴耳の不快レベルの左右差を, 前 項で述べた内耳性難聴の不快レベルの左右差の散布度に 関する基淮と較べてみたのが第 5 表である.

良耳の不快レベルが，オージオメータの出力の限度に 近いために, スケール・アウトした後迷路性難聴耳との 不快レベルの差が, 果してこの基準に合致するものであ るかどらか不明であつたもの8 周波数を除いて計算する と，54例中 49 例( 1 周波数を 1 例とす), つまり90\%で判 定可能であった.

不快レベルの測定が，後迷路性難聴の診断の精度の上 い方法であることを示す所見であると考えられる。

第 5 表 不快レベルによる後迷路性難聴の鑑別 （太線より右が鑑別できたもの）

\begin{tabular}{|c|c|c|c|c|c|c|c|}
\hline & \multicolumn{5}{|c|}{ 不快レベルの左右差 } & \multirow{2}{*}{$\begin{array}{l}\text { スケール } \\
\text { アウトの } \\
\text { 為, 判定 } \\
\text { 不能であ } \\
\text { つたむの }\end{array}$} \\
\hline & & $\begin{array}{l}15 \mathrm{~dB} \\
\text { 以下 }\end{array}$ & $20 \mathrm{~dB}$ & $25 \mathrm{~dB}$ & $30 \mathrm{~dB}$ & $\begin{array}{l}35 \mathrm{~dB} \\
\text { 以上 }\end{array}$ & \\
\hline 気 & 下5dB 以 & 4 & \multicolumn{4}{|c|}{$35(1)$} & 5 \\
\hline $\begin{array}{l}\text { 關 } \\
\text { 值 }\end{array}$ & $\begin{array}{l}60,65 \\
d B\end{array}$ & \multicolumn{2}{|c|}{1} & \multicolumn{3}{|c|}{$5(1)$} & 3 \\
\hline $\begin{array}{l}\text { क } \\
\text { 左 }\end{array}$ & $\begin{array}{l}70,75 \\
\mathrm{~dB}\end{array}$ & \multicolumn{3}{|c|}{0} & \multicolumn{2}{|c|}{$6(1)$} & 0 \\
\hline $\begin{array}{l}\text { 右 } \\
\text { 差 }\end{array}$ & $\begin{array}{l}80,85, \\
90 \mathrm{~dB}\end{array}$ & \multicolumn{4}{|c|}{0} & $3(3)$ & 0 \\
\hline & 計 & \multicolumn{4}{|c|}{5} & $49(19)$ & 8 \\
\hline
\end{tabular}

M.U. 28才 女性 聴神経腫湐 (右) ^右耳 V左耳 不快レベル

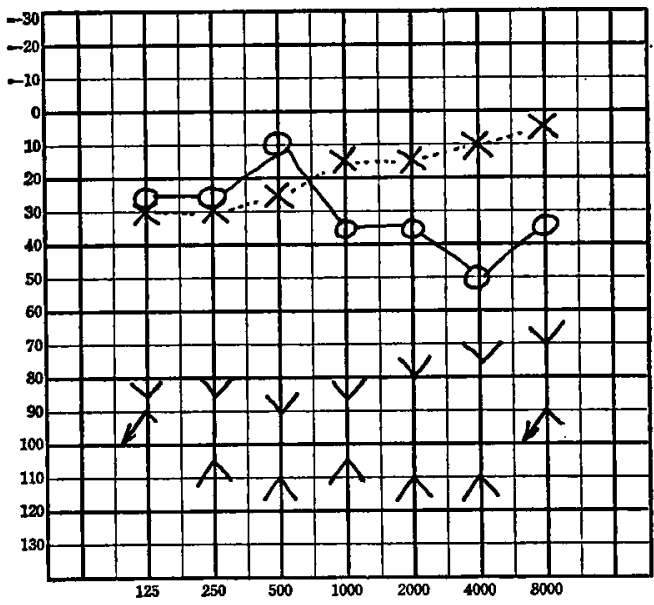

第 22 図

以上のことは，ひとつの周波数につき，どの程度の左 右差が生じたら後迷路性難聴の疑いがむたれるかを中心 に述べたわけだが,ここで不快レべルによる後迷路性難 聴の鑑別につきむら少し述べておくと，実際の後迷路性 難聴の症例では，そのオージオグラムを見ると，前述の ごとく気導聴力損失の少い部分でも，多い部分でも，不 快レベルは一見して明かな上昇を示するのなのである (第22図)，不快レベルの臨床的な応用を試みたSaltzman and Ersner (1954) $)^{10)}$, 新井13)—おそらく Bangs and Mullins 2)もそうであろら—はオージオグラムの上で, 直観的にレクルートメント現象の有無を判定している 
が，それはまた，後迷路性難聴の診断の埸合にも可能な ことなのである．ただ，場合によると，周波数によって は，その差が比較的小さいこともあり得るので，実際に は，不快レベルが良耳とくらべて全体的に上昇してい て，しかも，、くつかの周波数で前述の基準が满たされ ているような場合に, 後迷路性難聴と判定すればよいよ 5に思われる。

従って，両耳の不快レベルが非常に高値である時，あ るいは両耳とす不快レベルがスケール・アウトした時, あるいは片耳の不快レベルがオージオメータの出力の限 界纪近く，問題になる側の耳の不快レベルがスケール・ アウトした時などは，それだけでその耳が，あるいは両 耳が後迷路性難聴であると決めるのは危険である.

前二者に関しては, 聴力損失の差にかかわらず不快レ ベルの左右差は，ほぼ一定の範囲内におさまるものであ るから，同じ感音性難㯖では，一方の耳の不快レベルが 大きい值をとれば，他方の耳の不快レベルもやはりそれ に近い値をとるであろらからであるし，また，後者に関 しては，ある程度の左右差は常に起り得るものだからで ある。

また，片耳が正常ないし比較的軽度の難聴であつて， その耳の不快レベルよりも, 問題になる耳気導翏値の 方が大きい場合には，、がに不快レベルの左右差が大き くとも，判定を保留しなくてはならない場合があると思 われる.

この上うに，後迷路性難聴かどらか判定が難しい場合 も考えられるが，夷際には，私どもはこうした症例にほ とんど遭遇していない.

たとえ難聴が高度で, 他の聴覚検查で後迷路性難聴を 判定する充分な所見が得られない場合でも不快レベルの
測定は，かなり多くの症例をカバーできる応用箕围の広 い検査法であるといらことが，早期診断と並んでいえる と思われるのである.

=不快レベルとバランス・テストの関係=

ここで不快レベルとバランス・テストの関係を検矹し た結果を述べてみる。

第23図(1)に示したよ5に不快レベルとバランス・テス トの関保が判定できる場合と，第23図(2)に示したよ5 に, バランス・テストが不快レベルの現われる強さまで 行なわれていないために, バランス・テストの関係を示 す曲線を推定によつて延長して始めてその関倸が判定で きるものがあった。

内耳性難聴では36例中，完全に一致したもの10例，ほ とんどー致したもの 2 例, バランス:テストが両者を比 較するのに充分な強さまで行なわれていないが推定によ り平衡線を延長すると，大体一致する（良耳の不快レベ ルとパランスする，患耳に与えた音の強さと，患耳の不 快レベルの差が5dB 以内）と思われたもの20例で，かな り離れていると判定されたものは 4 例であつた.

後迷路性難聴では，一致していると判定されるものは 9例で,一致しなかつたもの3例であつた。

内耳性難聴では，不快レベルの測定值とバランス・テ ストの結果が一致したものは約 $90 \%$, 後迷路性難聴では 約75\%であつたことになる。つまり，不快レベルを生ず る強さの音性，両耳に等しい loudnessを生してている 考えることができる。

従来, 不快レベルの測定をレクルートメント現象の検 出に利用しょらとする考えには，当然こうしたことが 前提となつているわけだが，実際に不快レベルを利用す ることに疑問が持たれたのは，この成績からいえば，む

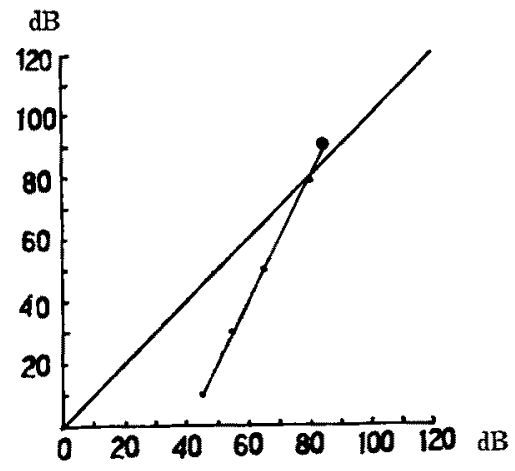

第23図(1) 平衡グラフ $(1000 \mathrm{~Hz})$ Y.O. 43才 男性 突発性難鳁

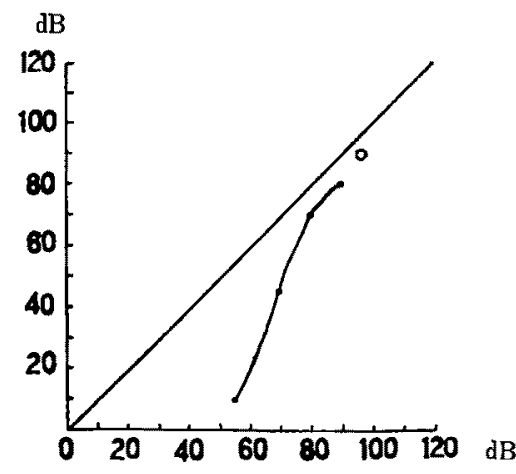

第23図(2) 平衡グラフ $(1000 \mathrm{~Hz})$

T.S. 51 才 女性 低音性感音性難聴 
しろ, 伝音性難聴, 後迷路性難聴には, 全くレクルー！ メント現象は見られず，内耳性難聴に注必ず明瞭なレク ルートメント現象が現われるはずだという仮定に誤りが あるためではないかと思われる，バランス・テストに限 つていえばそそれ程はつきりした差異住出てこないので はないかと思えるのである。

\section{VII 伝音性難聴}

ここで扱つた伝音性難㯖の内訳は，慢性中耳炎23例， 耳硬化症 10 例, 出性中耳炎 4 例, 耳小骨奇型 1 例, 臨 林的に耳硬化症と思われるが手術末施行で確診されてい ないもの10例の計48例（同側に伝音性難聴のあるものを 含む)である。

\section{[成績]}

不快レベルの測定值は，周波数别比第 $24 ， 25 ， 26 ， 27$ 28図に示してある。、ずれの図でも不快レベルが気導闘 值の上昇にともなって上昇してゆく傾向のあることが判 る.

例によつて気尊闒值および不快レベルの左右差を示し たのが第6表で,250〜 4000Hz を一括して表示してある.

F検定を行な5と一次回帰といえる（危険率 $1 \%$ ）の で，その回帰直線を求めたところ， $y=0.483 x+0.933$

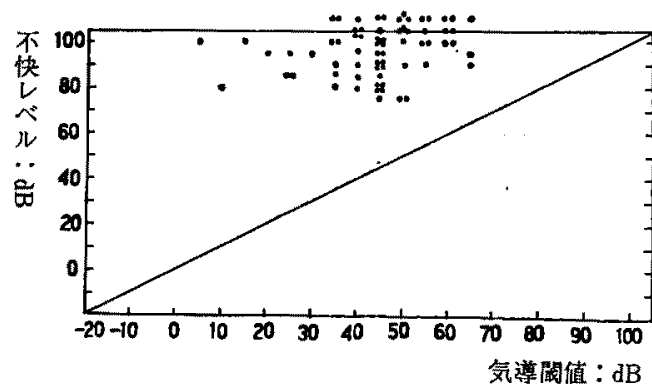

第24図 伝音性難聴耳の不快レベル $(250 \mathrm{~Hz})$

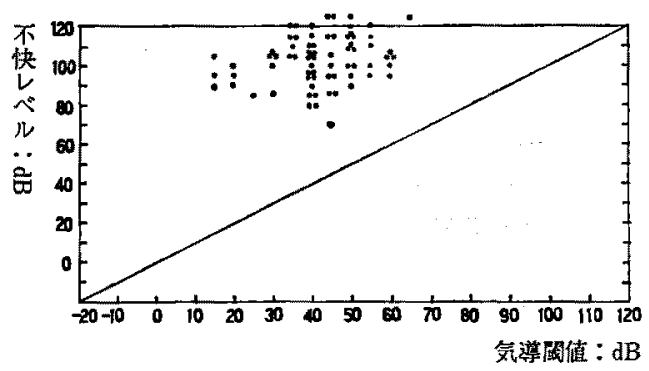

第25图 伝音性難聴耳の不快レベル $(500 \mathrm{~Hz})$

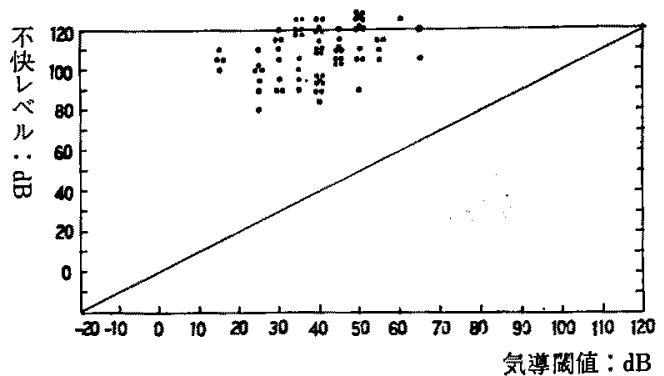

第26图 质音性難聴耳の不快レベル $(1000 \mathrm{~Hz}$

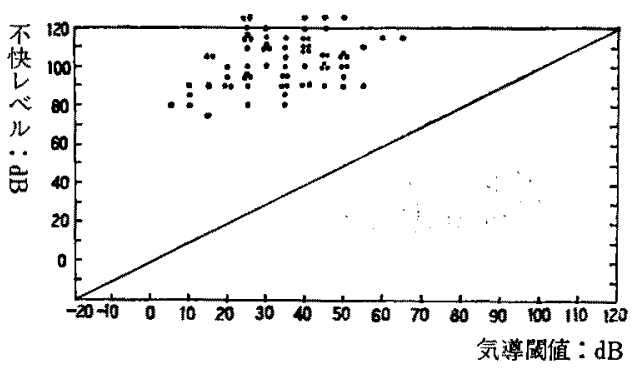

第27図 伝音性難聴耳の不快レベル $(2000 \mathrm{~Hz})$

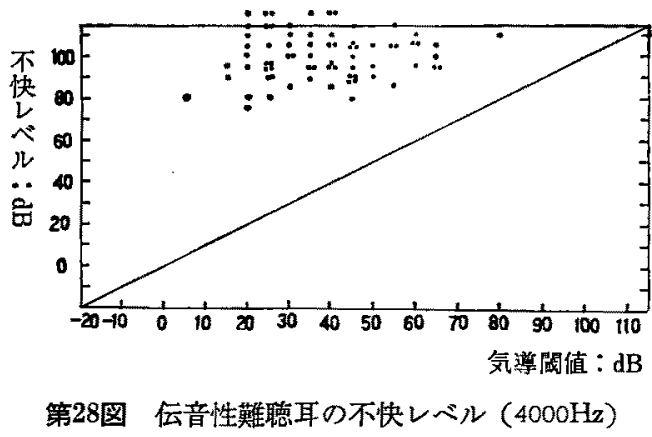

しなつた

感音性難㯖の場合と異りスケール・アウトしたるのの 占める比率肪大きいが，大体，原点を通る勾配 0.5 の直 線であるといえる.

回帰直：からの標潐偏差は7.452dB で，かなり正常者 の場合l近いが，やはり，これより大きい（F検定，危 険率 $5 \%$ ).

[考按]

著者の成續でいらと，伀音性難聴耳の不快レベルの上 刑は，気尊間值の上昇の大きさの 2 分の1づつしか起 つていないことになつた 
第 6 表 伝音性難聴耳における不快レベルの左右差 $(250 \sim 4000 \mathrm{~Hz})$

\begin{tabular}{|c|c|c|c|c|c|c|c|c|c|c|c|c|c|c|c|c|c|}
\hline & \multicolumn{15}{|c|}{ 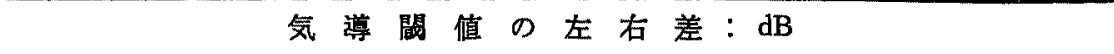 } & \multirow{2}{*}{ 計 } \\
\hline & & 0 & 5 & 10 & 15 & 20 & 25 & 30 & 35 & 40 & 45 & 50 & 55 & 60 & 65 & 70 & \\
\hline & 55 & & & & & & & & 1 & & & & & & & & 1 \\
\hline & 50 & & & & & & & & & & & & & & & & \\
\hline 不 & 45 & & & & & & & & & 2 & & & & & 1 & 1 & 4 \\
\hline 快 & 40 & & & & & & & 1 & & & & & 1 & 2 & & 1 & 5 \\
\hline$v$ & 35 & & & & & & & 2 & & & & & & & & & 2 \\
\hline ふ & 30 & & & & 1 & 1 & 1 & 2 & 5 & 1 & & 3 & 2 & 1 & 1 & & 18 \\
\hline ル & 25 & & & & 3 & 2 & 4 & 2 & 6 & 3 & 2 & 2 & 1 & & 1 & & 26 \\
\hline$\infty$ & 20 & & 3 & & 7 & 2 & 6 & 6 & 7 & 3 & 2 & 2 & & & & & 38 \\
\hline 左 & 15 & 1 & 3 & 2 & 7 & 2 & 8 & 5 & 3 & 5 & 3 & & 1 & & 1 & & 41 \\
\hline 右 & 10 & & 6 & 9 & 12 & 6 & 2 & 7 & 1 & 2 & 3 & 1 & & & 1 & & 50 \\
\hline 㱸 & 5 & 7 & 13 & 6 & 6 & 3 & 2 & 4 & 1 & & 1 & & & & & & 43 \\
\hline 0 & 0 & 17 & 11 & 10 & 7 & & 1 & 1 & & & & & & & & & 47 \\
\hline$\overline{\tilde{\pi}}$ & -5 & 7 & 3 & 3 & 3 & & & & & & & & & & & & 16 \\
\hline & -10 & & 3 & & 1 & & & 1 & & & & & & & & & 5 \\
\hline & -15 & 1 & & & & & & & & & & & & & & & 1 \\
\hline
\end{tabular}

Silverman の報告では, 感音性, 伝音性, 混合性難聴 を含んだ難聴者群の discomfort level は，正常者のそれ より約10dB 高いのみであり ${ }^{112}$, Lidén（1954）蛤音を 使用した不快レベルの測定では，伝音性難聴耳で注，正 常耳と比べて約5〜10dB 程度の上昇があつたに過ぎない といら ${ }^{8)}$.やはり，この関係を反映したものであろう。

Anderson and Barr (1968) 注，鐙骨筋反射を利用し て耳硬化症24例の検查を行ない，いずれも気導關値から 計算した值よりも低いところでこの反射が認められ，ま た, 両耳バランス・テストでも程度は高くないが明確な レクルートメント現象が認められたと述べている゙。.

従来，不快レベルを臨床に応用しようとした検討で は, レクルートメント現象陰性の代表として伝音性難聴 が選れている. 伝音性難聴にはレクルートメント現象が ないから不快レベルは気導閏値の上昇分だけ上昇するは ずであり，不快レべルの上昇しない内耳性難聴との鑑別 の基準が求められるであるらといら考えである.

ところが，実際には，不快レベルは個人閒のバラッキ が大きい上に，伝音性難聴耳の不快レベルは必ずしも気 導閶値の上年分ほどは上昇しないのである，そのため， 伝音性難聴耳と内耳性難聴耳の測定值は，かなり大きな 部分がかさなり合らので，この両者を明快に区別する基 準を作るのは難しいのである.これも，不快レベルを臨 林に応用することが，疑問視されてきたひとつの理由で
あろら。

大橋は、こらした伀音性難㯖耳に㧍ける不快レヘルの 傾向を，伝音性難聴では不快レベルが触党とか病覚の閶 值に近つくため, これらの感覚が関与してきて, 不快レ ベルが頭打ちになつたよらに予想より低、值で現れてく ると䗑明し14), Saltzman and Ersner は, 音のエネルギ 一が何万倍にもなつた時に, 闘値附近の強さの音の伝導 を妨げていた障害が，同しょうにこの枌はずれにエネル ギーの高い音を減衰せしめるとは限らないと述べてい $\varpi^{103}$.

その他,バランス・テストで伝音性難㯖にレクルートメ ント現象を歖めることがあるといら報告で柱, その原因 を耳小骨筋反射の異常に求めていることが多い715)193.

しかし、パランス・テスト伀音性難聴では, レクルー トメント現象の認められない場合の方が多いのも事実で ある、ただ，普通バランス・テストは，不快レベルに達 するような強さまで行なわれていないので，このあたり にも䦕題はあるかるしれない.

$$
=\text { 症 例 }=
$$

こらした伝音性難聴耳における不快レぶルの特微を踏 まえて検查を行なえば，時に臨床的に有益な所見の得ら れることがある. 別のところでも檤べた例であるが18), 一例としてあげてみる。

症例 K.S. 男性 54才 
K. S. 54才 男性 ヘ右耳 V左耳 不快レベル

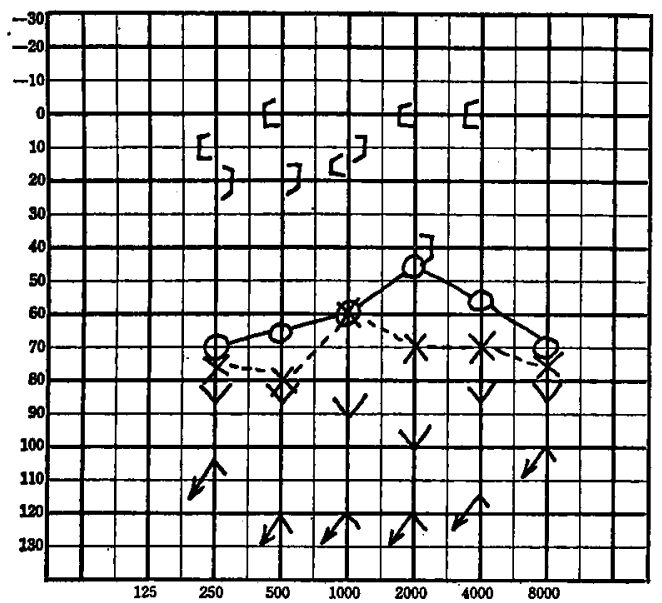

第 29 図

以前より右慢性中耳炎を指摘され，難聴を自営してい たが, 約10日前, 突然, 左耳の難聴と耳鳴に気付き来院 した.

初猃時, 右鼓膜に穿孔を認め, 左鼓膜は，ほぼ正常で あつた。

オージオグラムは第29図に示すごとく，一見して右耳 は伝音性，左耳は混合性難恥のごとく思われた。 しか し，この場合は当然骨尊測定に際してマスキングが不足 することが予想され，いずれかの骨遒は誤つて求められ たものである可能性が考えられた．そこで不快レベルを 測定してみると，右耳はスケール・アウトしていたが, 左耳は気導闇值にごく近、強さで認められた。

つまり，左耳は実は感音性難聴であるが，その骨導が 誤つて求められたものであることが推測できるかけであ る.

さて，この例で左耳に伝音性障害が関与していないで あろらかといら問題を検討してみることにする。

右耳の骨導は，誤つて求められる条件はないから，右 耳は，完全に伝音障害と考えてむよいであるう，そこで 右耳の不快レベルが，本来の值より，どの程度上年して いるかは，大体，その気導と骨導の差の 2 分の 1 である と推定できる.すなわち $250 \mathrm{~Hz}$ $1000 \mathrm{~Hz}$ で $22.5 \mathrm{~dB}, 2000 \mathrm{~Hz}$ で $22.5 \mathrm{~dB}, 4000 \mathrm{~Hz}$ で $27.5 \mathrm{~dB}$ である. むし，左耳に伝音性障害があるとすれば，その 大きさに比例して左耳の不快レベルも上昇しているはず であるから，本来の不快レペルは，実際の左耳の不快レ
ベルより低、值となると考えられる，それならば，不快 レベルの左右差は，上述の值より小さくなると考えられ る.そうなると，右耳の不快レベルはスケール・アウト せずに測定できる可能性が非常に大きくなってくる，と ころが，害際には右耳の不快レペルは全てスケール・ア ウトしているのである.もちろん，バラッキの大きい推 定であるから正確ではないが，左耳にはほとんど伝音性 障害が関与していないといら結論が得られるのである。

\section{胹 語音明瞭度との関係}

レクルートメント現象をともなら難聴では，auditory area が狭小となり，これをともなわない難聴では，気導 閵值が上䄯しても，この面積は不変であろう。

auditcry area の面積が変らなければ，充分に音を強 くしてやれば，語音明瞭度は，100\%に達するであろ5 が, auditory area が狭くなれば，例え音を強くしても語 音明膫度は100\%に達しないであろら。

こらいら考え方で, Huizing (1951)は，バランス・テ ストの結果を解釈しようとし6)，Zangemeister (1950) は 不快レベルを利用して，この幅を測定しようとしてい $\Xi^{12)}$.

つまり，気導曲線と不快レベルの差が，聴覚における dynamic range に相当し，この幅の変化が，語音明膫度 の成績を規定しているという考え方である。

第30図は，いずれも低音性感音性難㯖の症 例である が，右耳の気導曲線の形は非常によく似ている，ところ が(1)では，右耳の最高語音明膫度は78\%であつたが，(2) では $100 \%$ に達している，不快レベルを見ると，(2)では 全てスケール・アウトしている(この時はブースタを使 用していない）のに，(1)では，かなり気導間值に近いと ころで不快レベルが出現している，不快レベルが dynamic range を表わしているひとつの例と思われる.

しかし. 多くの内耳性難聴例で最高語音明瞭度と不快 レベル $(1000 \mathrm{~Hz})$ の関係を見ると，第31図のよ5に，そ の間に関係はみられるが，かなりバラッキが大きい。

このよらな難㯖耳に扔いては, auditory areaの歪みは 単に綎方向に生ずるばかりでなく，横方向つまり周波数 分析能の否みもまたとむならのではないかと思われ，従 つて語音明瞭度は必ずしも dynamic range の幅のみで 規定されているものではないのである.

この点についてはさらに進んだ検討が必要と思われ る.

\section{Hyperacusis}

これについては別の機会にも触れているので簡単に述 
T.H. 19才 女性 低音性感音性䢄聴 ヘ右耳 V左耳 不快レベル
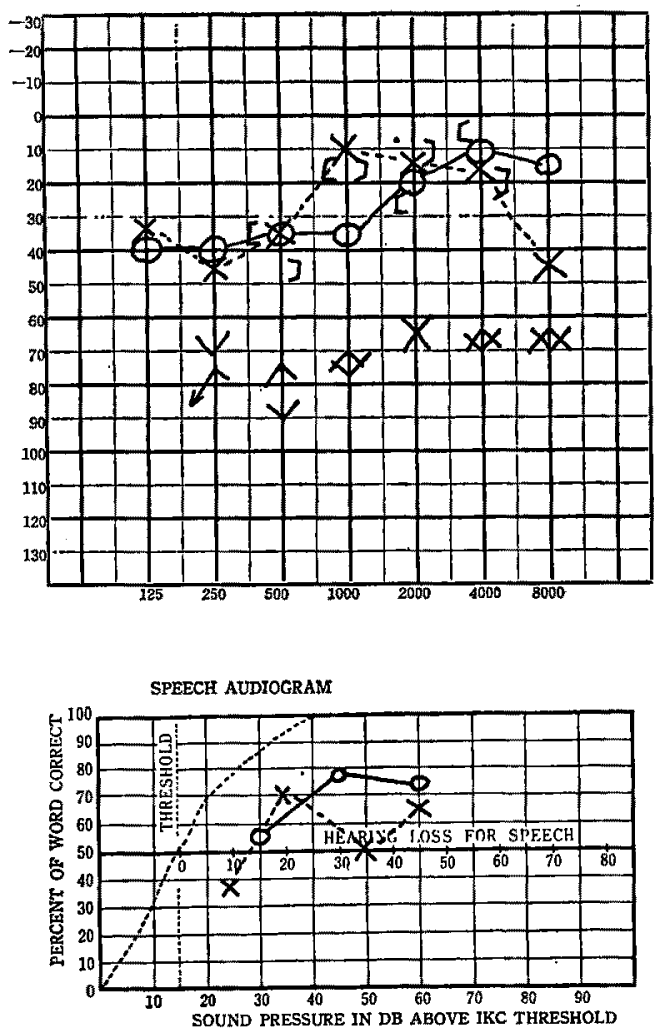

第 30 图(1)

ベることにする．

日常の智床で，聴力の障害琶認めないのに，大きな音 が耳にひびくと訴える症例に遭遇することが時々ある.

こ5した症例の中には顔面神経糜焷にともなつてくるむ のと，そうした症状を欠除するものとがある。前者につ いては，鐙骨筋の麻疸のために起るもので，顔面神経の 損傷部位の推定に役立つ所見であると考えられているの は周知のごとくである。

河村等 (1948) は, 末梢性顔面神経麻㾝の症例で, hyperacusisの訴えのあつたものにつき，バランス・テス トを行ない,レクルートメント現象の有無を調ベている が，聴力正常であつたもの19例のうち，8例にレクルー トメント現象のよらな変化がみられたと報告している゙'

著者が，この報告で扱つたのは，顔面神経麻㿎をとも なつたもの 4 例，その他のもの6例であつた，第 7 表 は，不快レベルの測定の結果を示しているが，顔面神経 麻䡋にともならもの4例中 2 例に不快レベルの下降の衣
I.T.45才 男性 低音性感音性難聴(右) ヘ右耳 V左耳 不快レベル
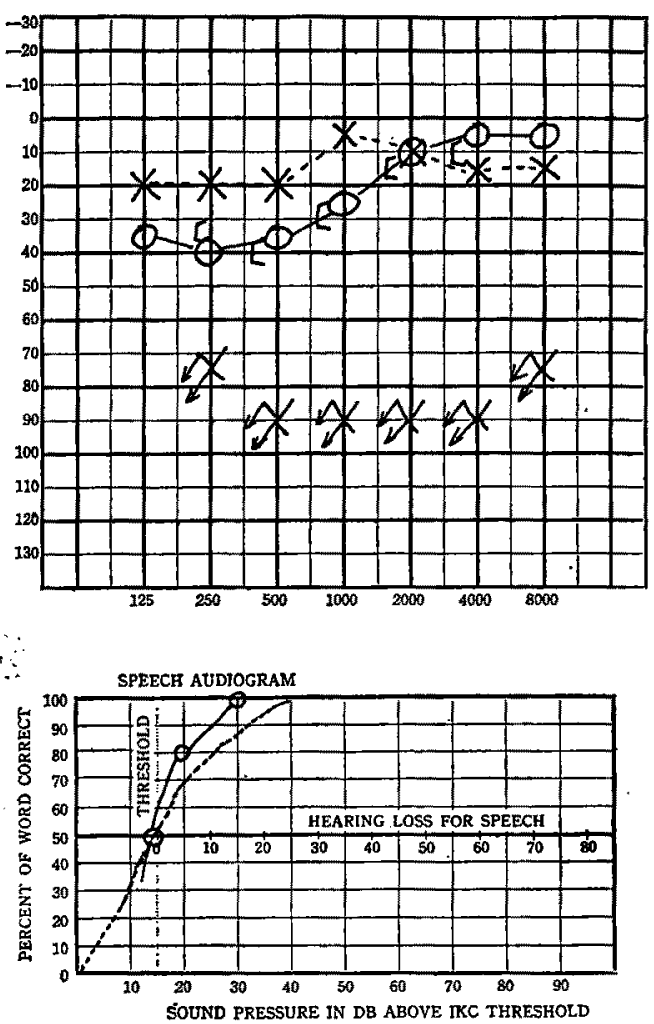

第 30 図(2)

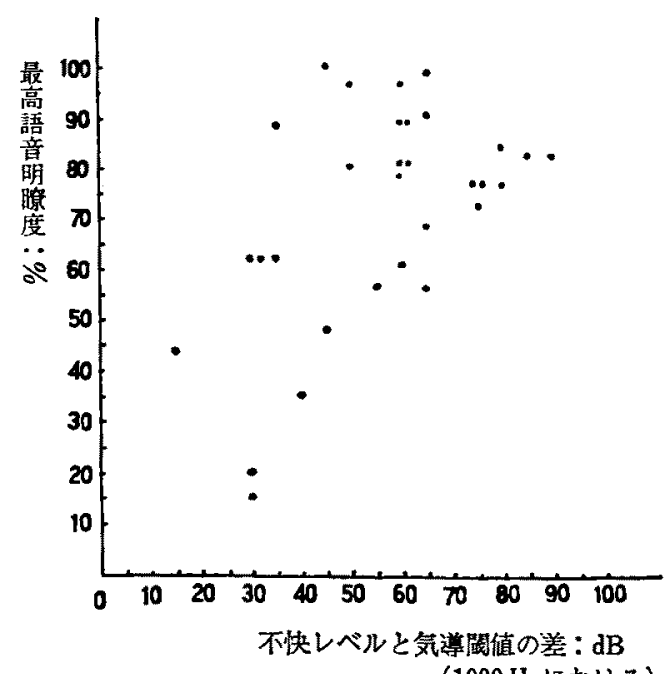

第31图 不快レベルと語音明膫度 


\begin{tabular}{|c|c|c|c|}
\hline & \multirow[t]{3}{*}{ 第 7 表 } & \multicolumn{2}{|c|}{ Hyperacusis } \\
\hline & & \multicolumn{2}{|c|}{ 不快レベルの下降 } \\
\hline & & $(+)$ & $(-)$ \\
\hline $\begin{array}{l}\text { 顔 } \\
\text { 面 } \\
\text { 神 }\end{array}$ & $(+)$ & 2 & 2 \\
\hline $\begin{array}{l}\text { 磨 } \\
\text { 㾝 }\end{array}$ & $(-)$ & 2 & 4 \\
\hline
\end{tabular}

見が得られており河村等の報告に一致する㓶合であると 思われた。また顔面神経麻疩が見られなかつた 6 例のう ち2 例に不快レベルの下降が認められている。

従来の聴力検查では異常の認氁隹いと思われるこれら の症例の中にも不快レベルの測定を行ならと，その訴え を裹付ける客観的な所見の得られることがあるわけであ る.

\section{$\mathrm{X}$ 結 び}

著者は, 正常者20名, 感音性難聴14名, 聴神経腫瘁 11 名, 脑幹部腫場による難恥者 4 名, 伝音性難聴 48 名, その他に純音による不快レベルの測定を行なつて以下の ような結諭を得た。

(1) 通常のオージオメータで測定を行ならと難聴耳で は，不快レベルがスケール・アウトすることが多く臨床 的に充分な所見が得られない場合が多いが，ブースタを 接続して出力を堌強するとほとんどの症例で診断の助け となる所見が得られるよらになる.ただし, その場合で も $125 \mathrm{~Hz}$ と $8000 \mathrm{~Hz}$ では不快レベルがスケール・アウト することが多いので,この二つの周波数の測定は省略し ても差支えない.

（2）正常者の成績を見ると，従来の報告とほぼ一致し た結果が得られている．また，個人差によるバラッキは かなり大きいが，左右差に着目すれば，これが $15 \mathrm{~dB}$ 越えることはまずないむのと推定される.

（3）感音性難㯖（後迷路性難聴を除く）では, 例えば メニエル氏病では，比校的低值で，老人性難聴では高 值で不快レベルが現れ，また低音性感音性難聴では，不 快レベルが広い簛囲にバラッイているといらょうに。難 聴の種類により幾分，不快レベルの現れ方に差がみられ る.

乙かし，一般的について気導聴力の差が $55 \mathrm{~dB}$ 以下で あれば，不快レベルの左右差は $15 \mathrm{~dB}$ を上まわることは ない。

それ以上の気導聴力損失の差があれば，
気導閵值の左右差 ： 不快レベルの左右差

$60,65 \mathrm{~dB} \quad$ : $20 \mathrm{~dB}$ 以下

$70,75 \mathrm{~dB} \quad$ : $25 \mathrm{~dB}$ 以下

$80,85,90 \mathrm{~dB}$ : $30 \mathrm{~dB}$ 以下

$95,100 \mathrm{~dB}: 35 \mathrm{~dB}$ 以下

の関保があると推定される.

（4）この成續をもとに，聴神経埂瘍および脳幹部腫瘍 による難聴. 険討すると，90\%の周波数が，この基準を 上をわる值を示していた．

なお，この場合, 聴力損失がごく柽度でも不快レベル の上昇が見られるので，不快レぶルの測定は㯖神経腫瘍 や脑幹部尰場による難聴の早期診断にも役立つものと考 えられる.

(5) 不快レベルの測定值と, バランス・テストの関係 を，平衡グラフの上でみると，内耳性難聴では $90 \%$ が， 聴神経隀場や脑幹部腫湟による難聴では $25 \%$ が一致した 值を示していた。

（6）伝音性難聴では，両耳間の差をみると，不快レ心゙ ルは，気遒闑值の差の 2 分の 1 差を呈することが判 る.この関係性，実際の症例の鑑別診断に役立ちらるも のである.

（7）語音明瞭度と不快レベルの間には，ある程度関倸 があるが，バラッキが大きいので語音明膫度は，不快レ ベルのみが規定されるとはいえない．

（8）聴力障害をともなわない hyperacusis の症例の診 断に不快レベルの測定が役立つことがある。

\section{文献}

1) Anderson, H. and Barr, B.: Conductive Recruit ment. Acta Otolaryng., 62; 171, 1968.

2) Bangs, J.L. and Mullins, C.J.: Recruitment Testing in Hearing and its Implications. Arch. Otolaryng., $58 ; 582,1953$.

3) Farrior, J.B.: Recruitment A to Z. Arch. Otolaryng., $68 ; 37,1958$.

4) Hood, J.D. and Poole, J.P.: Tolerable Limit of Lcudness : Its Clinical and Physiological Significance. J. Acoust. Scc. Am., $40 ;$ 47, 1966.

5) Hood, J.D.: Observations upon the Relationship of Loudness Disccmfort Level and Auditory Fatigue to Scund-Pressure Level and Sensation Level. J. Accust. Scc. Am., 44 ; 959, 1968.

6) Huizing, H.C.: The Recruitment Factor in Hearing Tests. Acta Otolaryng., $40 ; 297,1951$. 
7) Lansberg, M.P.: Modern Aspects of the Recruitment Phenomenon. Arch. Otolaryng., 59; 712, 1954.

8) Lidén, G.: Speech Audiometry. Acta Otolaryng., Suppl. 114, 1954.

9) Littler, T.S.: The Physics of the Ear. Pergamon Press, 1965.

10) Saltzman, M. and Ersner, M.S.: The Growth of Loudness. Arch. Otolaryng. 59 ; 76, 1954.

11) Silverman, S.L.: Tolerance for Pure Tones and Speech in Normal and Defective Hearing. Ann. of Otol., $56 ; 658,1947$.

12) Zangemeister, von E.E.: Über den Lautstärkeausgleich (Recruitment). Acta Otolaryng., 38 ; 484, 1950.

13）新并邦夫：レクリートメント検㚗法としての快道大 いさ曲線。耳耳䠦，47；400，1955.

14）大橋 格：不快感発現音響強度閥 (Uncomfortable loudness level) 飞関する研究。日耳䑻，63；1032， 1960.

15）河辺義孝：音の強さと大きさの関保に就ての研究. 日耳角，58；971，1955.

16）河村正三他：顔面神経麻㾝比随伴せる “Hypera- cusis" 。日耳年, 61；870, 1958 。

17）切替一郎他：㯖觉検查法, 医学書院, 1964.

18）古賀度次郎他：不块レベル (UCL) の臨床的态用. オーシオロジー，11；23，1968.

19）立木 孝：Recruitment 測定法の检尌（1）。耳眼， $28 ; 13,1956$

20）立木 孝他：Recruitment 湘定法の检討 (3). 耳喉, $28 ; 403,1956$.

21）松䗁 久：聴覚に於汀る不快感及び疼痛感飞関する

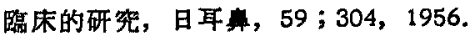

稿を終るに臨み，御指導御校閲を賜つた恩師鉿木 安恒教授に，心から感謝の意を表します。また終始

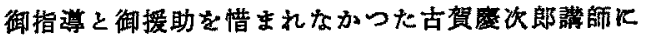
深く感謝の意を捧げると共に，䋓えず御協力を頂い た教室員各位に感謝いたします。

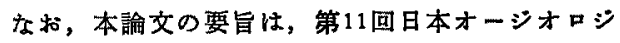
一学会, 第12回日本オージオロジー学会, 第70回日 本耳孟咽喉科学会総会飞於て発表した。

（原稿受付 昭和 $45,7,10$ 日） 